\title{
How to Conduct Prospective Life Cycle Assessment for Emerging Technologies? A Systematic Review and Methodological Guidance
}

\author{
Nils Thonemann *(i), Anna Schulte and Daniel Maga \\ Department of Sustainability and Resources Management, Fraunhofer Institute for Environmental, Safety, \\ and Energy Technology UMSICHT, 46047 Oberhausen, Germany; anna.schulte@umsicht.fraunhofer.de (A.S.); \\ daniel.maga@umsicht.fraunhofer.de (D.M.) \\ * Correspondence: nils.thonemann@umsicht.fraunhofer.de
}

Received: 6 January 2020; Accepted: 4 February 2020; Published: 7 February 2020

\begin{abstract}
Emerging technologies are expected to contribute to environmental sustainable development. However, throughout the development of novel technologies, it is unknown whether emerging technologies can lead to reduced environmental impacts compared to a potentially displaced mature technology. Additionally, process steps suspected to be environmental hotspots can be improved by process engineers early in the development of the emerging technology. In order to determine the environmental impacts of emerging technologies at an early stage of development, prospective life cycle assessment (LCA) should be performed. However, consistency in prospective LCA methodology is lacking. Therefore, this article develops a framework for a prospective LCA in order to overcome the methodological inconsistencies regarding prospective LCAs. The methodological framework was developed using literature on prospective LCAs of emerging technologies, and therefore, a literature review on prospective LCAs was conducted. We found 44 case studies, four review papers, and 17 papers on methodological guidance. Three main challenges for conducting prospective LCAs are identified: Comparability, data, and uncertainty challenges. The issues in defining the aim, functionality, and system boundaries of the prospective LCAs, as well as problems with specifying LCIA methodologies, comprise the comparability challenge. Data availability, quality, and scaling are issues within the data challenge. Finally, uncertainty exists as an overarching challenge when applying a prospective LCA. These three challenges are especially crucial for the prospective assessment of emerging technologies. However, this review also shows that within the methodological papers and case studies, several approaches exist to tackle these challenges. These approaches were systematically summarized within a framework to give guidance on how to overcome the issues when conducting prospective LCAs of emerging technologies. Accordingly, this framework is useful for LCA practitioners who are analyzing early-stage technologies. Nevertheless, further research is needed to develop appropriate scale-up schemes and to include uncertainty analyses for a more in-depth interpretation of results.
\end{abstract}

Keywords: prospective life cycle assessment (LCA); emerging technologies; systematic review; case studies

\section{Introduction}

During the development of emerging technologies, the potential contribution of these technologies to sustainable development is concerning. Life cycle sustainability assessments combine economic aspects with environmental and social dimensions [1]. Economic aspects can be captured by life cycle costing (LCC) [2], whereas social impacts are covered by social life cycle assessment (sLCA) [3-5]. A life cycle assessment (LCA) is applied to determine the environmental impact 
assessment of services or products [6-8]. However, these methods are lacking in their prospective assessments, which is particularly true for LCAs since they often exclusively examine these emerging technologies at a lab-scale [9-12]. Hence, scaling effects should be included when assessing emerging technologies [13-16]. In particular, a prospective LCA is needed for a comparative assessment of emerging and mature technologies. Ensuring the comparability of the LCA results from emerging and mature technologies supports process engineers when developing potentially environmentally friendly solutions.

Arvidsson et al. [17] conducted a systematic review of the environmental assessment of emerging technologies. They aim to provide recommendations on how to conduct prospective LCAs. They defined an LCA as prospective "when the (emerging) technology studied is in an early stage of development (e.g., small-scale production), but the technology is modeled at a future, more-developed stage (e.g., large-scale production)." Prospective LCAs are also called anticipatory [18] or ex-ante LCAs [19]. For a more in-depth discussion on the definitions of different modes of LCA including future states of product systems, see Cucurachi et al. [19] and Buyle et al. [20]. The LCAs scrutinized by Arvidsson et al. [17] deal with nanomaterials, biomaterials, and energy technologies. They differentiate between two approaches in prospective inventory modeling, namely predictive scenarios and scenario ranges for both foreground and background system modeling. The first approach strives to reflect likely developments with the status quo in mind. In order to build predictive scenarios, technology learning curves can be used [17]. The second approach includes extreme scenarios, which can be obtained by stoichiometric relationships to analyze the best-case scenario. Data sources for modeling the foreground systems are scientific articles, patents, expert interviews, unpublished experimental data, and process modeling. Life cycle inventory (LCI) databases are mostly used for the background systems. Additionally, the authors propose to omit the background system in order to assess the environmental impacts of an emerging technology independent from an over the time changing background system. While the work of Arvidsson et al. [17] is the most comprehensive review in the field of prospective LCAs, there is no claim to completeness. This incompleteness is mainly due to the lack of a definition of the term "prospective LCA" before their study was published. Moreover, the selection of case studies is not transparent, since the authors do not present their methodological approach.

Cucurachi et al. [19] discuss obstacles for ex-ante LCAs of emerging technologies. They define ex-ante LCAs as those that "scale-up an emerging technology using likely scenarios (e.g., using expert help, extreme views, learning curves for similar technologies) of future performance at full operational scale;" furthermore, the researchers "compare the emerged technology at scale with the evolved incumbent technology." According to the authors, the main obstacles for conducting ex-ante LCAs are seen in the lack of information on the projected final system and on the projected unit process data as well as in the missing characterization factors of emerging environmental impacts. In order to discuss these obstacles, a literature-screening approach was adopted. Still, the selection of the case studies was not complete, as the authors themselves mentioned.

Buyle et al. [20] build upon the work of Arvidson et al. [17] and Cucurrachi et al. [19]. As a result, Buyle et al. [20]. contribute a framework for conducting ex-ante LCA. Additionally, they provide a profound difference between the following terms: Prospective, anticipatory, and ex-ante LCA. The developed framework comprises methods and approaches categorized into three technology stages: Technology development, technological learning, and technology diffusion. Moreover, the different methods and approaches are aligned to the technology readiness level (TRL) scale.

Moni et al. [21] conducted a review on LCAs of emerging technologies and identified challenges. The major methodological challenges in conducting LCAs of emerging technologies are comparability, data availability and quality, scaling, and uncertainty. Additionally, Moni et al. [21] compile suggestions to overcome these issues. However, several current studies on how to conduct prospective LCAs of emerging technologies are missing in this review although the review was published recently. Moreover, the article lacks a methodology section on how the review was conducted and how the 
analyzed papers were selected. Therefore, the reader is unclear from Moni et al.'s [21] review on the studies used to base their findings.

So far, several studies describe the application of prospective LCAs [22-27]. Nonetheless, no general framework for conducting prospective LCAs is given and no comprehensive systematic literature review on LCAs of emerging technologies has been conducted until now. Thus, this study aims to answer the research question, "How can LCAs be prospectively applied to emerging technologies?" In order to answer the research question, we conducted a systematic literature review of relevant case studies and analyzed methodological approaches for conducting prospective LCAs of emerging technologies. As a result, we have developed a framework for tackling the challenges, which are of particular importance when conducting prospective LCAs of emerging technologies. This framework is particularly useful for LCA practitioners who are analyzing the potential impacts of a future state of early-stage technologies.

\section{Methodology}

Fink's [28] methodological approach and the specific instructions for systematic reviews of LCAs [29] were followed in order to conduct the literature review. In order to discover relevant articles, keywords were defined according to our research question. In order to find literature that focuses on emerging technologies, we chose the search strings "emerging technolog*", "novel product", "technolog* maturity", "early research technolog*", "scaling technolog*", "laboratory plant*", "pilot plant", "novel proces*", "early research" in combination with the environmental assessment related strings "life cycle assessment*" (LCA*), "Prospect* LCA", "Scal* LCA", "ex-ante LCA", "Project* LCA", "Predict* LCA". The search was conducted in the period from October to December 2019 using the primary databases JSTOR (www.jstor.org/), ScienceDirect (www.sciencedirect.com/), Scopus (www. scopus.com/), SpringerLink (www.link.springer.com/), Web of Science (www.webofknowledge.com/), and Wiley Online Library (www.onlinelibrary.wiley.com/). Publications found are roughly selected via titles and abstracts. After that, a second content-related check of the literature was carried out. Publications that did not relate to our research questions or were duplicates were excluded. Therefore, in detail, we limited our analysis to publications that were published in peer-reviewed journals and observed:

- Emerging technologies defined in Rotolo et al. [30] as "a relatively fast-growing and radically novel technology characterized by a certain degree of coherence persisting over time and with the potential to exert a considerable impact on the socio-economic domain(s) which is observed in terms of the composition of actors, institutions, and the patterns of interactions among those, along with the associated knowledge production processes."

- An LCA case study or methodological paper on how to conduct prospective LCAs on emerging technologies or systematic reviews on LCAs of emerging technologies.

- LCAs that are focused on the future of early-stage technologies and evaluate the emerging technology in a forward-looking manner (scale-up).

The literature search ended when new results did not introduce new methodological approaches or case studies [28]. Next, by following the approach of content analysis by Mayring et al. [31], we analyzed the selected articles in order to answer the research question. Accordingly, we identified the challenges encompassed in the prospective LCA of emerging technologies and analyzed how these challenges were tackled in the case studies. The procedure for the systematic literature review is given in Figure 1. 


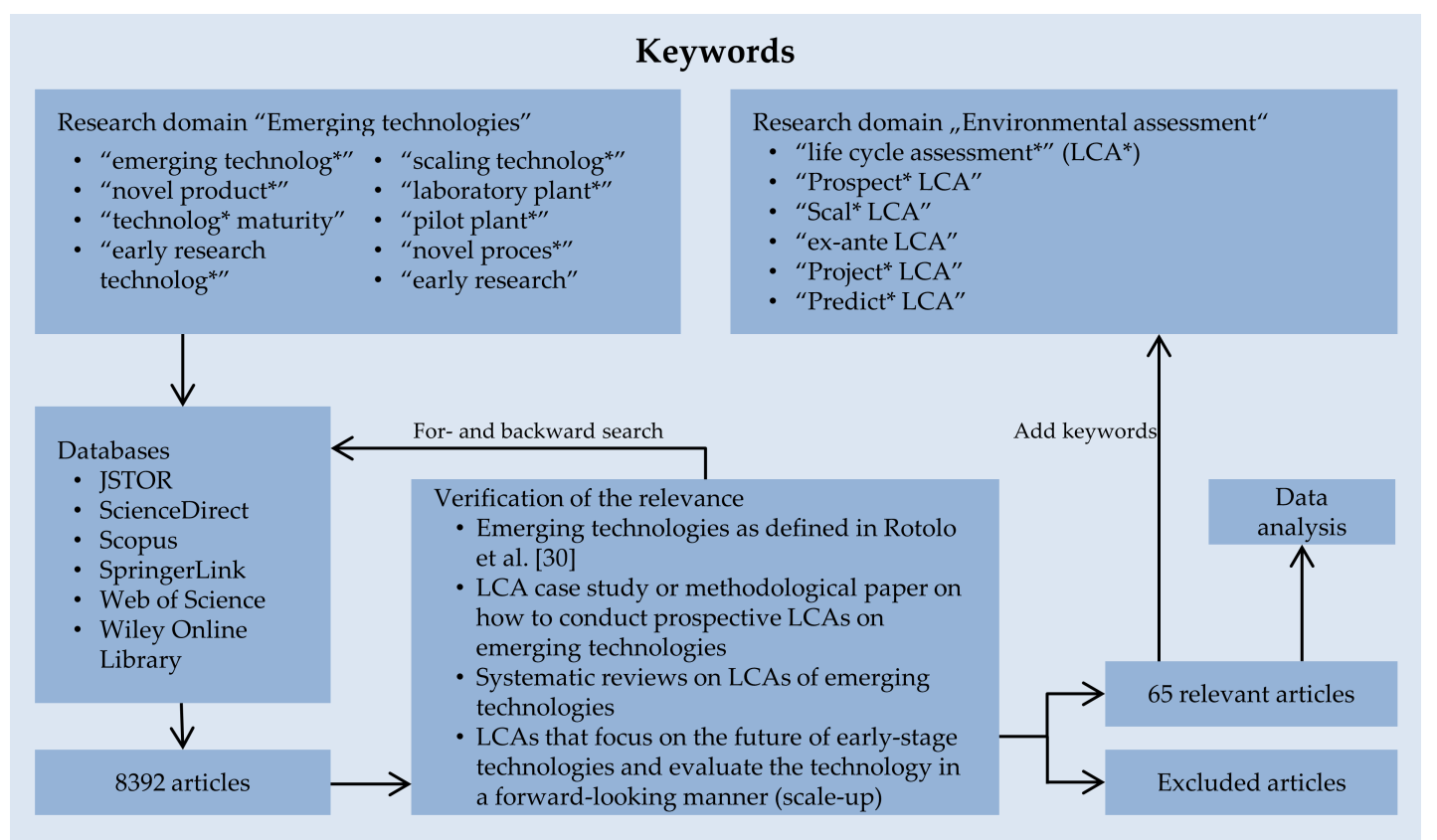

Figure 1. Procedure of the systematic literature review.

\section{Results and Discussion}

By following a structured keyword search, we found 65 publications. From the identified articles, 44 publications were published as case studies, whereas 17 publications provided methodological guidance on how to perform prospective LCAs on emerging technologies. The remaining four publications were published as review articles. Figure 2 shows the temporal, or time-based, evolvement of the publications on LCAs and emerging technologies. The first studies published describe methodological guidance on how to perform prospective LCAs. Following that, several case studies were published that are also summarized and analyzed in the four recently published review studies. In the last two years, the number of publications in the field of prospective LCAs on emerging technologies has plateaued at a constant number of 13 published articles per year. However, since the review was prepared in late 2019, the number of publications could still rise.

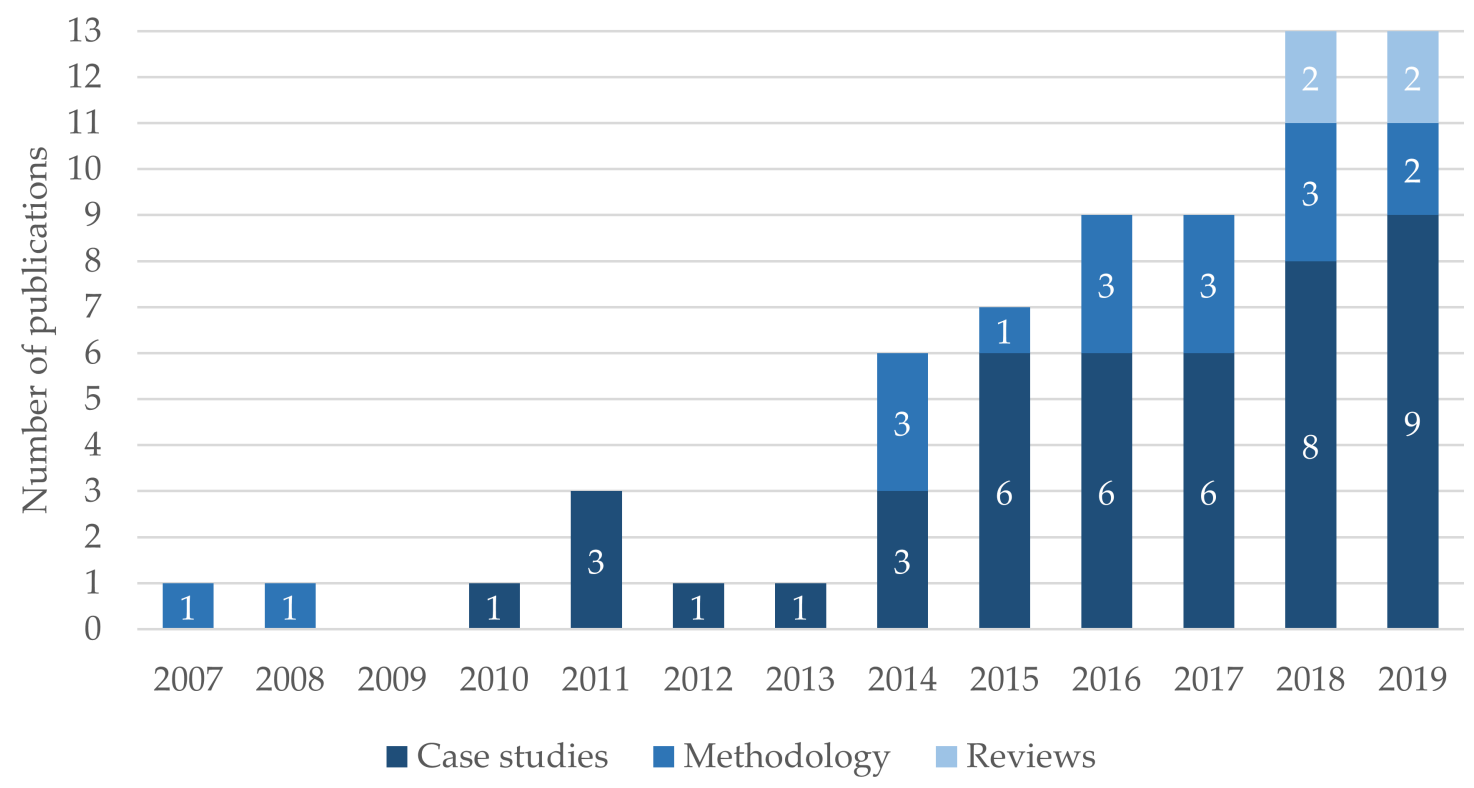

Figure 2. Temporal evolvement of the relevant publications. 
The main findings and methodological assumptions of the 44 case studies are discussed in the next section. Figure 3 provides an overview of the articles and the different topic areas of the case studies (a detailed overview is provided in the Supplementary Material Table S1). Eleven case studies were carried out that model the production of nanomaterials and chemicals, including chemical production ranging from the electrochemical formic acid production [32] to the production of specialty chemicals like caprolactam [33]. Energy production was assessed in seven case studies. Six case studies were performed within the field of wastewater treatment and five case studies evaluate biofuel production. The topics of food production $(n=4)$, mobility $(n=2)$, and biomass production $(n=1)$ are analyzed as well.

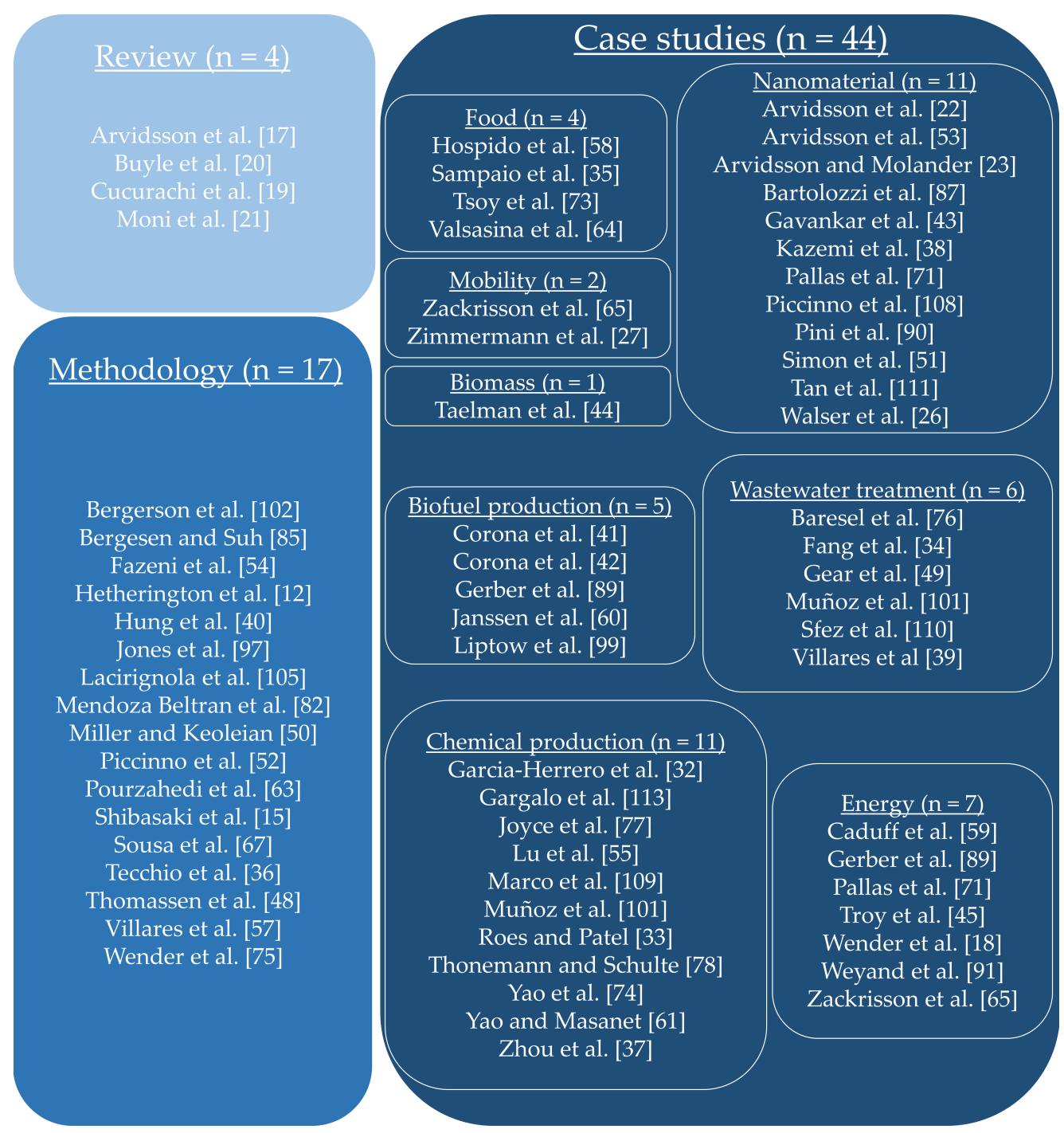

Figure 3. Overview of the analyzed studies.

Most authors concluded that applying prospective LCA is useful, leads to new insights during the development of new technologies, and can support policymakers in their work [25,26,32,34-37]. Zimmermann et al. [27] expand this argument in concluding that prospective LCAs lead to a more robust analysis than traditional static LCAs. The results are of significant relevance and presented as a contribution analysis so that a designer or process engineer can identify the processes that contribute the most to a specific environmental impact [38,39]. Since most freedom degrees exist at low TRLs, critical process steps should be identified as early as possible. Hung et al. [40] developed the so-called lifecycle screening of emerging technologies method (LiSET) to systematically assess the environmental impacts of emerging technologies at low TRL. 
After scale-up, the impacts are mostly lower when compared to the impacts of the lab-scale system [18,41-44]. Nevertheless, Arvidsson and Molander [23] found that scale-up behavior is case-specific and lower environmental impacts at a developed technology stage cannot be taken for granted. Additionally, the impacts of the scaled-up system are not often compared to the impacts of the mature alternative technology [45].

\subsection{Challenges in the Application of Prospective Life Cycle Assessments}

According to the results of the content analysis, we identified the challenges in comparability, data, and uncertainty (see Figure 4 for an overview). Hetherington et al. [12] highlight the challenges of using LCAs during the development of emerging technologies. They identified the following four challenges: Comparability, scaling issues, data availability, and uncertainty. However, we included the scaling issue to the data challenge as scaling is needed in order to generate inventory data for the scaled-up product system. The first challenge, comparability, focuses on the discussion of how prospective LCAs can ensure comparability between assessments of emerging and mature technologies. The comparability challenge is divided into the following definitional: The aim of the study, the functionality, the system boundary, and the choice of life cycle impact assessment (LCIA) methodologies. The second challenge, data, focuses on the challenges in data availability, data quality, and the scaling of inventory data. Uncertainty is the third challenge, which describes the situation of imperfect information, since uncertainty exists in every step in an LCA but especially within a prospective LCA for emerging technologies [12]. We analyzed the methodological papers and case studies for approaches to tackle the mentioned challenges and systematically providing the finding in the subsequent sections.

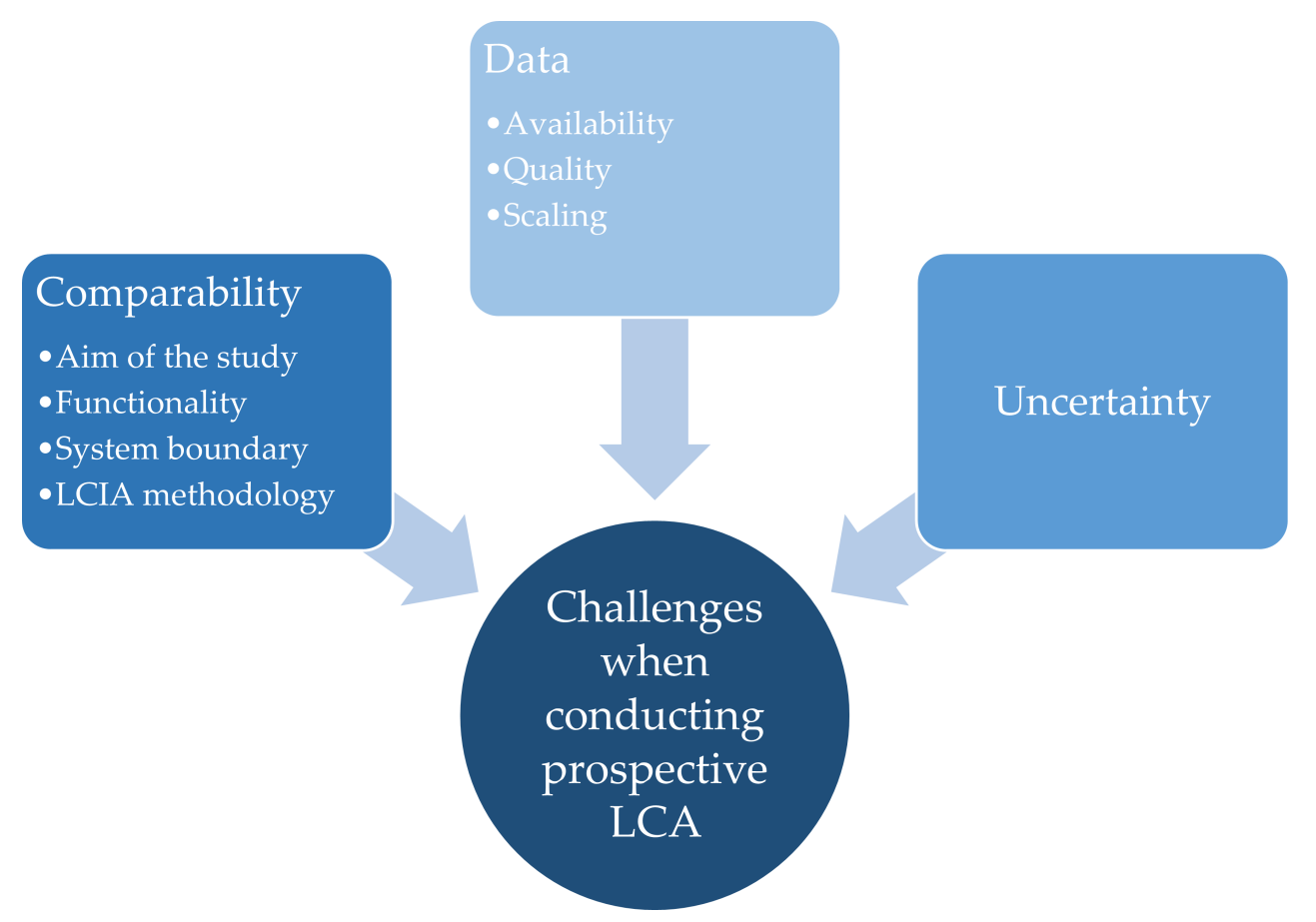

Figure 4. Schematic overview of the challenges for the application of prospective LCAs.

In this review article, the distinction into the chosen challenges can be regarded as a structuring element of this article in order to discuss the challenges systematically. The classification of the individual challenges into these categories is not to be regarded as strict since the challenges are overlapping. For example, uncertainty is an overarching aspect, which is also present in the comparability and data challenge. 


\subsubsection{Comparability}

Comparability issues occur in prospective LCAs when defining the aim of the study, the functional unit, system boundaries, and specifying the LCIA methodologies $[12,19,46,47]$. This finding is also valid for conventional LCA studies but is exacerbated for prospective LCAs on emerging technologies since the lack of knowledge is higher at an early stage.

Aim of the study

A sound definition of the aim of prospective LCAs is needed, which includes explicitly stating the intended application. To address this issue, Gavankar et al. [43] and Thomassen et al. [48] propose to include the TRL and manufacturing readiness level (MRL) when conducting an LCA on emerging technologies as an indicator of the maturity of the technology. The specific reasons for carrying out the study besides the intrinsically prospective character should be stated. This specification should entail a statement about whether the study is intended to be comparative. In the case of a comparative prospective LCA, the time at which the comparison is made (temporal development) and the level of maturity between the compared technologies (technological development) must be aligned to the same development stage for all modeled technologies. An LCA practitioner should specify the temporal and technological development when defining the aim of the study in order to ensure comparability.

In all studies, the aim is stated and precisely defined. In the majority of case studies, comparative LCA studies are conducted. However, there is a differentiation to be made between comparisons with other mature reference alternatives [32] or comparisons of the same technology at different stages of development (different TRLs), for example, lab-scale impacts compared to those of pilot-scale or industrial scale [23]. Additionally, authors compared emerging technologies at a future point in time. The comparison of emerging technologies at a future point in time helps to identify environmentally friendly emerging technologies today. All listed comparisons are found in the case studies. In the case of non-comparative LCAs, the aim is to identify hotspots often and to give guidance to industrial engineers for reducing environmental impacts during the design and development of new technologies [49].

\section{Functionality}

The functional unit is linked to a reference value needed for conducting LCAs and quantifies the performance of a product system $[7,8]$. Defining the functional unit is the second issue within the comparability challenge as the dedicated function of the observed early-stage system may not be fully known. Systems at an early stage are susceptible to change when scaled up [12]. Miller and Keoleian [50] emphasize this point by stating that additional functionality develops as products mature. Hischier et al. [46] conducted an LCA case study on nanomaterials and found that the main factor for variations in the outcome depends on a comprehensively and adequately defined functional unit. Therefore, it is necessary to define ranges for the functional unit or multiple functional units in order to evaluate variations when assessing emerging technologies. Simon et al. [51] describe a framework that includes the functional analysis of a specific lab-scale process, which is useful for the definition of system functions.

Conversely, methodological approaches for prospective LCAs in the chemical industry assume the same functionality at the lab- and commercial-scale [15,36,52], and as for chemicals, identical properties are assumed [36]. Within the analyzed case studies, output-based definitions of functional units (e.g., the production of $1 \mathrm{~kg}$ of a specific chemical) outweigh input-based definitions of functional units (e.g., the treatment of $1 \mathrm{~kg}$ of waste in a treatment facility).

Several authors mentioned specific issues while defining the functionality of their observed system. Arvidsson et al. [22]; Arvidsson and Molander [23]; Arvidsson et al. [53] and Wender et al. [18] are aware of the functionality issue and noticed the issues concerning the definition of the functional unit. Still, the authors did not vary the functional unit in their studies and, therefore, did not investigate the 
effects of different functional units. This approach would allow the analysis of the full function along the life cycle, including the application and end-of-life. Moreover, the authors exclude other applications by defining a specific quality of the material, since other application fields require other functional units [22,39]. Among the case studies, it is noteworthy that when the application is not apparent at the lab-scale, authors are more cautious in defining the functional unit. The definition of the functional unit is rather straight-forward if a prospective LCA is applied to a product, which is dedicated to substitute a specific product. Still, this approach can lead to inaccurate results, since uncertainty in up-scaling exists and can result in a changed or decreased functionality.

\section{System boundary}

System boundaries set the criteria and specify which unit processes are part of the product system. The most comprehensive definition of system boundaries reaches from cradle (e.g., extraction of raw materials) to the grave (e.g., end-of-life treatment). Defining the system boundary is the third issue within the comparability challenge, as, for instance, detailed specifications for the use and end-of-life stage are unknown at an early stage. This is the case for already established recycling options for products produced via mature technologies and potential competitive advantages $[46,54,55]$.

Suh et al. [56] state that the choice of system boundary probably influences rankings in comparative studies. Hence, using results based on incorrectly selected system boundaries could lead to erroneous conclusions and decisions on the product to promote. Leaving out certain life cycle stages in an LCA could lead to an incomparability of results [12]. Excluding life cycle stages in LCAs on emerging technologies is not the only issue. Excluding life cycle stages of mature technologies might also lead to inconsistent boundaries and hampers comparability, as Miller and Keoleian [50] mention. For example, while it is common practice to exclude these impacts when assessing fossil fuel technologies, impacts from infrastructure are included when assessing renewable energy technologies. In order to deal with uncertainties regarding the definition of system boundaries, several authors recommend varying the system boundary and setting assumptions for little-known life cycle stages $[12,54,57]$.

Mostly, the authors of the case studies do not mention issues when setting the system boundary of their study. Nevertheless, some authors explained their choice. Hospido et al. [58] state that the quality of the produced product determines the downstream processing. In other words, if the novel process affects the quality of a product, then the downstream processes have to be taken into account. Otherwise, the use and end-of-life stages are often identical and can be neglected [39]. However, while conducting prospective LCAs, equality of life cycle stages should not be taken for granted [59]. End-of-life scenarios for emerging technologies are often unknown and the system boundaries are restricted due to perceived higher uncertainty [60]. Sampaio et al. [35] change the system boundaries according to market changes and include possibly affected upstream activities in defined scenarios. Wender et al. [18] state that it is essential to include different modeling of multiple system boundaries. Yao and Masanet [61] differentiate the setting of system boundaries for prospective LCAs in the chemical industry for chemicals consumed as final products, such as plastic bottles, and intermediate chemicals, such as carbon monoxide. For final products in the chemical industry, the system boundaries should comprise of the use phase and the end-of-life stage. System boundaries for intermediate products exclude the use and end-of-life phases as these stages are assumed to be identical in the downstream processing.

\section{Life Cycle Impact Assessment Methodology}

Assessing environmental impacts within LCA requires LCIA methods. LCIA methods translate the inventory data into distinct burdens on the environment. The EC-JRC [62] recommends LCIA methods on midpoint and endpoint level. When specifying the LCIA methodology, issues lie in the rapid development of technologies, which outpace the development of LCIA models [19]. Thus, the selection of LCIA methodologies needs to be as comprehensive as possible and must include the 
newest developments. Flawed conclusions could be drawn if the emerging technology causes impacts in today's unknown impact categories at a future point in time. Hence, emerging technologies could cause unknown impacts in the future, which are not covered due to missing LCIA categories [63]. Furthermore, different characterization factors are available for several impact categories. Therefore, Hischier et al. [46] propose to calculate the LCA results with different characterization factors.

Among the reviewed studies, LCIA methods at the midpoint outweigh those at the endpoint level. Using endpoint level indicators increases uncertainty. Arvidsson et al. [22] excluded impact categories (global warming and acidification impacts), which are mainly influenced by background data [64]. Such an approach contradicts the overall goal of an LCA to assess all environmental impacts of a product system. Therefore, Wender et al. [18] integrate risk research into their methodological approach for the scale-up. Nonetheless, risk assessment for newly introduced chemicals can take decades [18]. Still, Zackrisson et al. [65] show how to perform a qualitative chemical risk assessment when performing prospective LCA. In the case of assessments in the early-design stage, data availability is often limited, and consequently, the determination of all impact categories is mostly impossible [66]. Furthermore, the potential impacts of new substances on the environment may be neglected, since their impacts have not been sufficiently investigated. This can either be due to missing LCIA categories, insufficient LCI data, or the lack of knowledge about new impacts.

\subsubsection{Data}

The second challenge encountered when applying prospective LCAs is about data. Data availability is low for emerging technologies and is higher at an early-stage of development (low TRL) compared to data availability at the prospectively assessed developed-stage (high TRL). In order to obtain the inventory data for emerging technology at a developed-stage and at a future point in time, the product system needs to be projected from an early-stage in the technological and the temporal development to the developed-stage. This so-called scaling is challenging when conducting the life cycle inventory phase of a prospective LCA. The issue within the data challenge concerns the quality of data used within a prospective LCA. For instance, data quality is decreasing while scaling.

\section{Availability}

The data availability issue when conducting prospective LCAs of emerging technologies is about the lack of data that describes the emerging processes $[12,50,54,67]$. The scarcity of data, however, exists in conventional LCAs, but in prospective LCAs for emerging technologies, this issue is exacerbated, especially when assessing emerging technologies $[17,19]$. In our review, we differentiate between foreground and background data. Foreground data refers to those processes that are specific to the product system [62]. Background data is defined as data from processes, and due to the averaging effect across the suppliers, a homogenous market with average data can be assumed to represent the respective process appropriately [62]. Most authors state that the data availability for modeling the foreground system is most crucial [54]. Still, the data for modeling the background system is essential as well, since the background system is also subject to changes over time [17].

For a more in-depth analysis, a further distinction between data availability at lab-scale and prospective commercial-scale is necessary [19]. Modeling the foreground system at lab-scale mostly relies on primary data, such as experimental data for the observed system. In order to model the foreground system at commercial-scale, different data sources are available [17]. Data sources could be scientific articles, patents, expert interviews, unpublished results, and process simulations. This data is then used to predict the scale-up. In the case studies reviewed, data from literature, lab-scale and pilot plants, experiments, chemical equations, simulations, and patents (see Figure 5) are used for modeling the foreground system of the lab-scale LCI. 


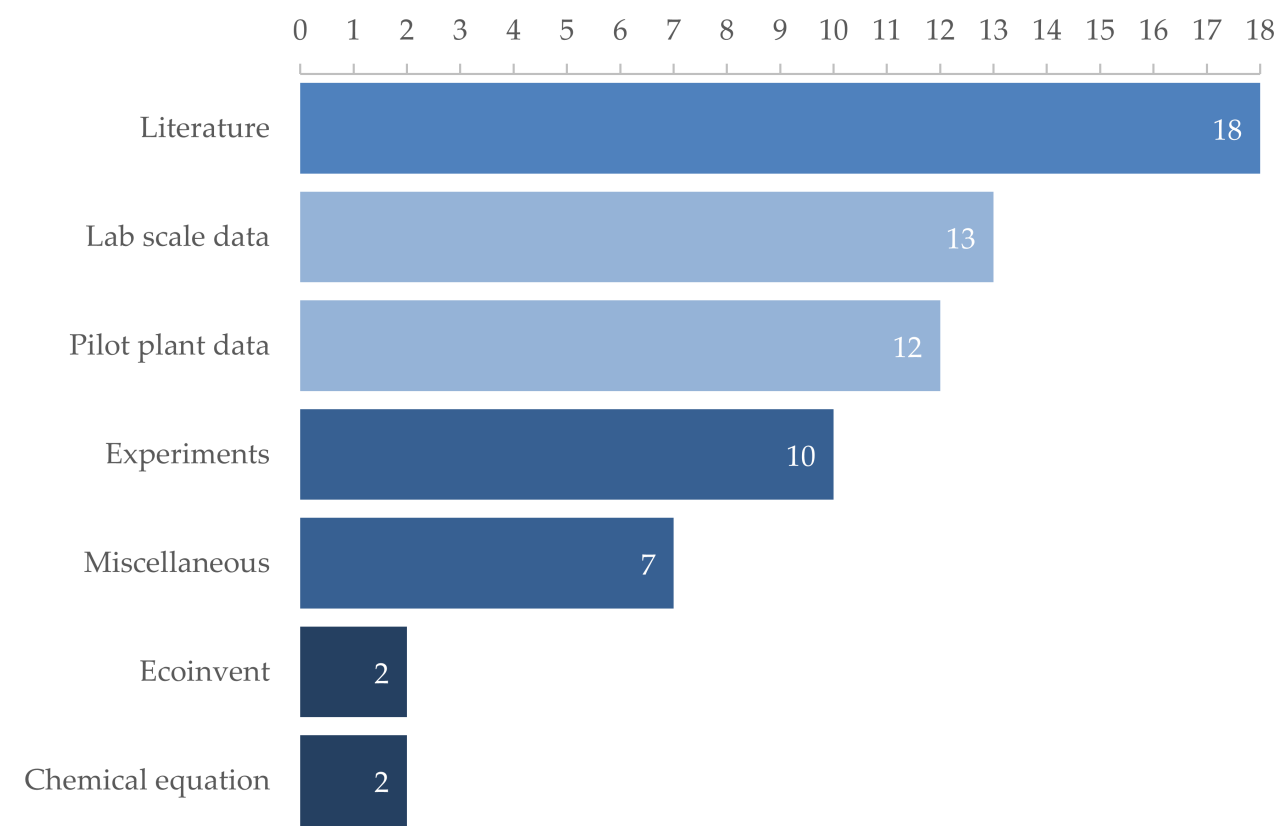

Figure 5. Type of data used for the lab-scale LCI of the reviewed studies.

Background data for the lab-scale could be obtained from databases such as ecoinvent [68] or $\mathrm{GaBi}$ [69]. Moreover, Arvidsson et al. [17] propose to omit the background system. This approach is independent of temporal development but goes against conventional LCA practice and comparability. Cucurachi et al. [19] suggest overcoming the data availability challenge using the so-called CLiCC-Tool. The CLiCC-Tool is a tool used to estimate inventory or impact data for certain substances using an artificial neural network [70]. In all studies except one, background data is used, and the reader is informed about that fact. In one study, background data is neglected because the time of application is unknown and the background model could be adopted in the future according to the specific future conditions [22]. In the other case studies, the ecoinvent database or literature is used to illustrate the background processes. In order to emphasize the origin of the data (lab-scale or commercial-scale data) and whether the data concerns the fore- or background, a color code within the system describing flow sheet is helpful $[65,71-74]$.

Quality

Besides data availability, data quality is also of concern [12]. The data quality issue is containing the suitability of data for a specific application. Fazeni et al. [54] propose facilitating communication between process engineers and LCA practitioners in order to improve data availability and data quality. According to Piccinno et al. [52], data quality is lower when a process is studied that will be deployed in the future. In addition, data quality issues are also of concern when obtaining data for the emerging technology at a developed stage. These future developments include technology-specific commercial-scale manufacturing inventories, use-phase product performance, end-of-life disposal pathways, life cycle material releases, and risk-relevant properties [75].

In 33 case studies, the authors made no statement on data quality. Authors of six case studies qualitatively discuss the data quality issue $[18,37,39,49,76,77]$. While in five case studies, a data quality index is applied. Data quality indices are used in conventional LCA to assess data quality. Gavankar er al. [43], Sampaio et al. [35], Thonemann and Schulte [78], Walser et al. [26], and Zimmermann et al. [27] propose to use the pedigree matrix formerly developed by Weidema and Wesnæs [79] to assess data quality. However, the further developed pedigree matrix and modification for assessing data quality of data sets within the ecoinvent database $[80,81]$ is applicable for conventional non-prospective data (see Figure 6). Figure 6 indicates the indicator scores among the data quality specifying the criteria: Reliability, completeness, temporal correlation, geographical correlation, and further technological 
correlation. According to the pedigree matrix, the data quality is surpassingly lower for the data of product systems at a developed stage and at a future point in time than compared to data of product systems at an early stage and at a current point in time. The values determined via the pedigree matrix can be used for uncertainty analysis using a Monte Carlo simulation [37]. Gear et al. [49] introduce a method that relies on techniques that can be applied in process design in early stages without requiring high data quality. Data quality could be increased by using integrated assessment models, at least for background data [82]. Villares et al. [39] justify the use of different data quality due to comparability.

\begin{tabular}{|c|c|c|c|c|c|}
\hline Indicator score & 1 & 2 & 3 & 4 & 5 (default) \\
\hline Reliability & $\begin{array}{l}\text { Verified data based } \\
\text { on measurements }\end{array}$ & $\begin{array}{l}\text { Verified data partly } \\
\text { based on } \\
\text { assumptions or } \\
\text { non-verified data } \\
\text { based in } \\
\text { measurements }\end{array}$ & $\begin{array}{l}\text { Non-verified data } \\
\text { partly based on } \\
\text { qualified estimates }\end{array}$ & $\begin{array}{l}\text { Qualified estimate } \\
\text { (e.g. by industrial } \\
\text { export) }\end{array}$ & $\begin{array}{l}\text { Non-qualified } \\
\text { estimate }\end{array}$ \\
\hline Completeness & $\begin{array}{l}\text { Representative data } \\
\text { from all sites } \\
\text { relevant for the } \\
\text { market considered, } \\
\text { over an adequate } \\
\text { period to even out } \\
\text { normal fluctuations }\end{array}$ & $\begin{array}{l}\text { Representative data } \\
\text { from }>50 \% \text { of the } \\
\text { sites relevant for the } \\
\text { market considered, } \\
\text { over an adequate } \\
\text { period to even out } \\
\text { normal fluctuations }\end{array}$ & $\begin{array}{l}\text { Representative data } \\
\text { from only some sites } \\
(<50 \%) \text { relevant for } \\
\text { the market } \\
\text { considered or }>50 \% \\
\text { of sites but from } \\
\text { shorter periods }\end{array}$ & $\begin{array}{l}\text { Representative } \\
\text { data from only one } \\
\text { site relevant for the } \\
\text { market considered } \\
\text { or some sites but } \\
\text { from shorter } \\
\text { periods }\end{array}$ & $\begin{array}{l}\text { Representative- } \\
\text { ness unknown or } \\
\text { data from a small } \\
\text { number of sites and } \\
\text { from shorter } \\
\text { periods }\end{array}$ \\
\hline $\begin{array}{l}\text { Temporal } \\
\text { correlation }\end{array}$ & $\begin{array}{l}\text { Less than } 3 \text { years } \\
\text { of difference to the } \\
\text { time period of the } \\
\text { dataset }\end{array}$ & $\begin{array}{l}\text { Less than } 6 \text { years } \\
\text { of difference to the } \\
\text { time period of the } \\
\text { dataset }\end{array}$ & $\begin{array}{l}\text { Less than } 10 \text { years } \\
\text { of difference to the } \\
\text { time period of the } \\
\text { dataset }\end{array}$ & $\begin{array}{l}\text { Data from area } \\
\text { with slightly } \\
\text { similar production } \\
\text { conditions }\end{array}$ & $\begin{array}{l}\text { Age of data } \\
\text { unknown or more } \\
\text { than } 15 \text { years of } \\
\text { difference to the } \\
\text { time period of the } \\
\text { dataset }\end{array}$ \\
\hline $\begin{array}{c}\text { Geographical } \\
\text { correlation }\end{array}$ & $\begin{array}{l}\text { Data from area } \\
\text { under study }\end{array}$ & $\begin{array}{l}\text { Average data from } \\
\text { larger area in } \\
\text { which the area } \\
\text { under study is } \\
\text { included }\end{array}$ & $\begin{array}{l}\text { Data from area } \\
\text { with similar } \\
\text { production } \\
\text { conditions }\end{array}$ & $\begin{array}{l}\text { Data from area } \\
\text { with slightly } \\
\text { similar production } \\
\text { conditions }\end{array}$ & $\begin{array}{l}\text { Data from } \\
\text { unknown or } \\
\text { distinctly different } \\
\text { area (North } \\
\text { America instead of } \\
\text { Middle East, } \\
\text { OECD-Europe } \\
\text { instead of Russia) }\end{array}$ \\
\hline $\begin{array}{c}\text { Further } \\
\text { technological } \\
\text { correlation }\end{array}$ & $\begin{array}{l}\text { Data from } \\
\text { enterprises, processes } \\
\text { and materials under } \\
\text { study }\end{array}$ & $\begin{array}{l}\text { Data from } \\
\text { processes and } \\
\text { materials under } \\
\text { study but from } \\
\text { different } \\
\text { technology }\end{array}$ & $\begin{array}{l}\text { Data from } \\
\text { processes and } \\
\text { materials under } \\
\text { study but from } \\
\text { different } \\
\text { technology }\end{array}$ & $\begin{array}{l}\text { Data on related } \\
\text { processes or } \\
\text { materials }\end{array}$ & $\begin{array}{l}\text { Data on related } \\
\text { processes on } \\
\text { laboratory scale } \text { or } \\
\text { from different } \\
\text { technology }\end{array}$ \\
\hline
\end{tabular}

Figure 6. Pedigree matrix adapted from Ciroth et al. [80] (italic font indicates data of product systems at a forecasted developed stage (high TRL) that cannot fulfill the specified criteria).

Scaling

The scaling issue is about the development of scale-up scenarios that predict the performance of the future process by applying realistic assumptions. The main obstacle for prospective LCAs is to generate reliable and consistent inventory data for the examined technology at a future point in time with high TRL by up-scaling the emerging technology $[17,43,83]$. Scaling implies an increase in the physical size of a process, which leads to an increase in the production capacity $[15,16,84]$. In a broader sense, the projected emerging technology within prospective LCAs implies prospective process improvements, for example, an increase in the degree of energy efficiency due to heat integration. Simon et al. [51] differentiate between process and system scaling. Process scaling includes the preparation of an LCI for a potential commercial-scale process. System scaling characterizes the effects which are induced on the market when the scaled-up process is deployed.

Hence, scaling is another issue for conducting prospective LCA. Within the methodological papers, different approaches for dealing with scaling challenges with the foreground system are proposed. To handle scaling challenges in the foreground system, Bergesen and Suh [85] present a framework based on learning curves that observe the supply chain of a technology. This framework can be used 
to study the effects of different drivers of technological change throughout the supply chain of a technology. Such a framework can help predict the changes in both the environmental impacts and the resource requirements of a technology, and furthermore, it is applicable for prospective LCAs. Sousa et al. [67] explore a method for preliminary LCAs using learning algorithms. Learning rates for electricity-supplying activities have been reviewed and analyzed by Rubin et al. [86] and can be applied within LCA studies. These algorithms are trained using the already acknowledged characteristics of existing products. Fazeni et al. [54] propose a framework for conducting an LCA parallel to the essential process development, especially for biorefineries. Starting from an LCI, which is based on lab results and literature findings, the scale-up is based on a detailed flowchart and the knowledge of process engineers. Piccinno et al. [52] provide a framework on how chemical lab processes can be scaled up for LCA purposes. The framework was applied in the case study of Bartolozzi et al. [87] to develop a scale-up model. Shibasaki et al. [15] report on a systematic approach that allows predicting commercial-scale plant impacts based on LCI data of pilot plant processes. Tecchio et al. [36] present a protocol aiming at forecasting the environmental impacts of new polymers through a more effective and effortless approach. In doing so, they use a scale-up function based on data of the pilot-scale plant, data of the commercial-scale plant of the reference material, and the stoichiometric ratio for a best-case estimate. Caduff et al. [10] developed scaling factors for 508 heat pumps and furnaces and concluded that the scaling behavior is comparable to cost scaling. This approach can also be applied to other processes. Villares et al. [57] reflect on the usefulness of an ex-ante LCA application for near future scaling using scenarios based on proxy technologies and estimated data.

In the reviewed case studies, several methods are applied for generating inventory data for the up-scaled process. Mainly predictive scenarios (73\%) are used and, in almost one-third of the reviewed studies $(27 \%)$, scenario ranges are conducted. For obtaining the scale-up data, the authors of the reviewed studies use different sources. Predictive scenarios are mostly established using simulation results [32,41,42], literature findings, input from experts [88], modeling data [34], assumptions [77], and other calculations [89]. Besides that, initial base cases [49], full-scale estimates [58], data from experiments [90], power laws [91], risk analysis [18], design modifications [49], and (linear) scaling rates [90] are applied. Arvidsson et al. [22] argue that even independent researchers can conduct a prospective LCA since the relevant data for their analysis was found in patents and scientific papers. Information on how to set up scenario ranges is limited. Some authors apply assumptions, simulations, modeling data, multidimensional matrices, power laws, and superstructures for implementing scenario ranges. Spielmann et al. [25] establish a method for scenario construction. In the first step, technology and socio-economic variables are identified (selection of scenario variables), and in the second step, these variables are used to identify key variables (structural analysis). Pesonen et al. [92] advise on how to develop scenarios in LCA and have identified the two basic approaches: What-if scenarios and cornerstone scenarios. Another approach to building scenarios was published by Sharp and Miller [93]. The authors propose to use principles from the research field of innovation diffusion to construct scenario models for prospective LCA.

For background modeling, the scaling challenge is mainly about the technical specifications of processes in the background that are modeled at a future point in time. Since this data mostly relies on efficiency gains, as expected for windmills or photovoltaics, the efficiency effects should be taken into consideration. Therefore, in order to conduct a comprehensive prospective LCA, the technical progress should be modeled for the background as well. Nevertheless, as emerging technologies evolve, background system modeling at a commercial-scale is not straightforward. Data for electricity supply in the future is available [13] and generated by forecasting models, whereas data availability for future heat supply is scarce. Arvidsson et al. [17] suggest modeling the background system according to future scenarios in order to overcome the temporal mismatch between the foreground and the background model. Mendoza Beltran et al. [82] propose a novel approach for tackling the scaling challenge in background system modeling by systematically changing the background processes in a prospective LCA that is based on the scenarios of an integrated assessment model. Cox et al. [94] apply 
an integrated assessment model that includes changes within the provision of electricity when it is used in current and future battery electric vehicles. Gibbon et al. [95] propose an integrated hybrid life cycle assessment model in order to forecast the environmental impacts of emerging technologies ex-ante by using climate mitigation scenarios. Van der Voet et al. [96] environmentally assess different metal demand scenarios. The outcome of this model can be introduced in prospective LCAs in order to cover datasets for metal production in the future. Finally, another approach to overcome the scaling challenge is to model the whole LCA consequentially [97]. The change-oriented approach includes marginal suppliers and is prospectively intrinsic. However, Jones et al. [97] state that prospective consequential background data also needs to be adapted for future conditions. Still, attributional and consequential LCA can be applied retro- and prospectively [98]. As Arvidsson et al. [17] pointed out, one barrier for prospective LCAs occurs when choosing the background data relevant to a future point in time to which the data is projected. Only a small number of case studies choose the background data in such a way $[27,60]$. The majority use static background data, since the background systems are expected to change slightly [99]. Several authors highlight the importance of using different background data as these changes can have a considerable influence on the overall results $[17,22,23,100]$. Nevertheless, only two of the authors apply a consequential modeling approach to take future market developments into account [78,101]. However, Bergerson et al. [102] and Buyle et al. [20] state that it is crucial to describe the market and technological characteristics as they influence the outcome of a prospective LCA of emerging technologies.

\subsubsection{Uncertainty}

Huijbregts et al. [103] differentiate three different types of uncertainty in LCAs. The parameter uncertainty is due to uncertain input data. Scenario uncertainty occurs because LCA outcomes are based on normative choices in the modeling procedure. Model uncertainty occurs due to the mathematical models used in LCA. All types of uncertainty occur in prospective LCAs. The focus in this paper lies in parameter and scenario uncertainty, since these uncertainty types are frequently found in prospective LCAs of emerging technologies [50]. Scenario uncertainty is especially encountered when making assumptions in the goal and scope phase [50] and when choosing boundary conditions for up-scaling schemes [52]. Parameter uncertainty is present at every development stage, and Hetherington et al. [12] describe the degree of uncertainty is highest at the beginning of the development of a technology. Therefore, it is necessary to discuss the results with caution and also to integrate uncertainty analyses whenever possible.

Cooper and Gutowski [104], Lacirignola et al. [105], Marini and Blanc [106], Ravikumar et al. [107] and Wender et al. [75] focus on uncertainty analyses within prospective LCAs. Cooper and Gutowski [104] propose an approach for the selection of probability distributions in order to model inputs using empirical data. Lacirignola et al. [105] established a procedure to examine the robustness of global sensitivity analysis results and to identify critical inputs. Marini and Blanc [106] describe a method to identify parameters that contribute to the overall uncertainty within prospective LCAs by using Sobol indices. Ravikumar et al. [107] introduce a statistical test in order to find significant differences in LCA results between emerging technologies. Wender et al. [75] support the development of anticipatory LCAs, which can be used to discover reasonable and extreme-case scenarios of upcoming environmental burdens related to an emerging technology. Gavankar et al. [83] stress the importance of communicating uncertainty in LCAs of emerging technologies and propose a five criteria framework, which can be applied for interpretation purposes.

In the case studies, uncertainty was addressed and discussed in different manners. Many assumptions and uncertainties are involved in the case of scale-up calculations [108]. Roes and Patel [33] describe the main uncertainties within their analysis comprehensively, whereas, in other studies, no statement is made on the uncertainty of input data or results $[32,42,44,45,76,99,109-111]$. Several authors address uncertainty with sensitivity analyses to account for parameter variation [22,38,53,60]. Arvidsson and Molander [23] state that the results 
depend on the temporal development and thus influence the degree of uncertainty since both foreground and background system can change over time. Fang et al. [34] conduct a contribution and a perturbation analysis for analyzing uncertainty and sensitivity, which was recommended by Clavreul et al. [112]. The most used approach in the studies that includes parameter uncertainty is the Monte Carlo method [26,35,37,61,89,94,113]. Gargalo et al. [113] conclude that an uncertainty analysis enables a more in-depth interpretation and concurrently improves the transparency and robustness of the reached conclusions. Gavankar et al., Sampaio et al., and Wender et al. [18,35,43] used the pedigree matrix approach [114] to estimate parameter uncertainties (see data quality section). Wender et al. [18] state that the inclusion of an uncertainty analysis throughout modeling is essential for decision-driven LCAs.

\subsubsection{Integrated Overview of the Examined Challenges}

The previous sections have shown that the handling of the challenges in prospective LCAs is often different in the methodical papers and the case studies. Studying the objective of the case studies reveals that prospective LCAs were applied as a comparative assertion in all cases except for one. However, different types of comparisons between the emerging technology, conventional technology, or among different emerging technology were executed in the case studies. In this review, we suggest that not all types of comparisons found in the case studies are in line with the applied definition of a prospective LCA. For example, in several types of comparisons, the alignment of the temporal or the technological development is neglected, which leads to incomparability. In Figure 7, we illustrated different types of comparisons found in the context of prospective LCA.

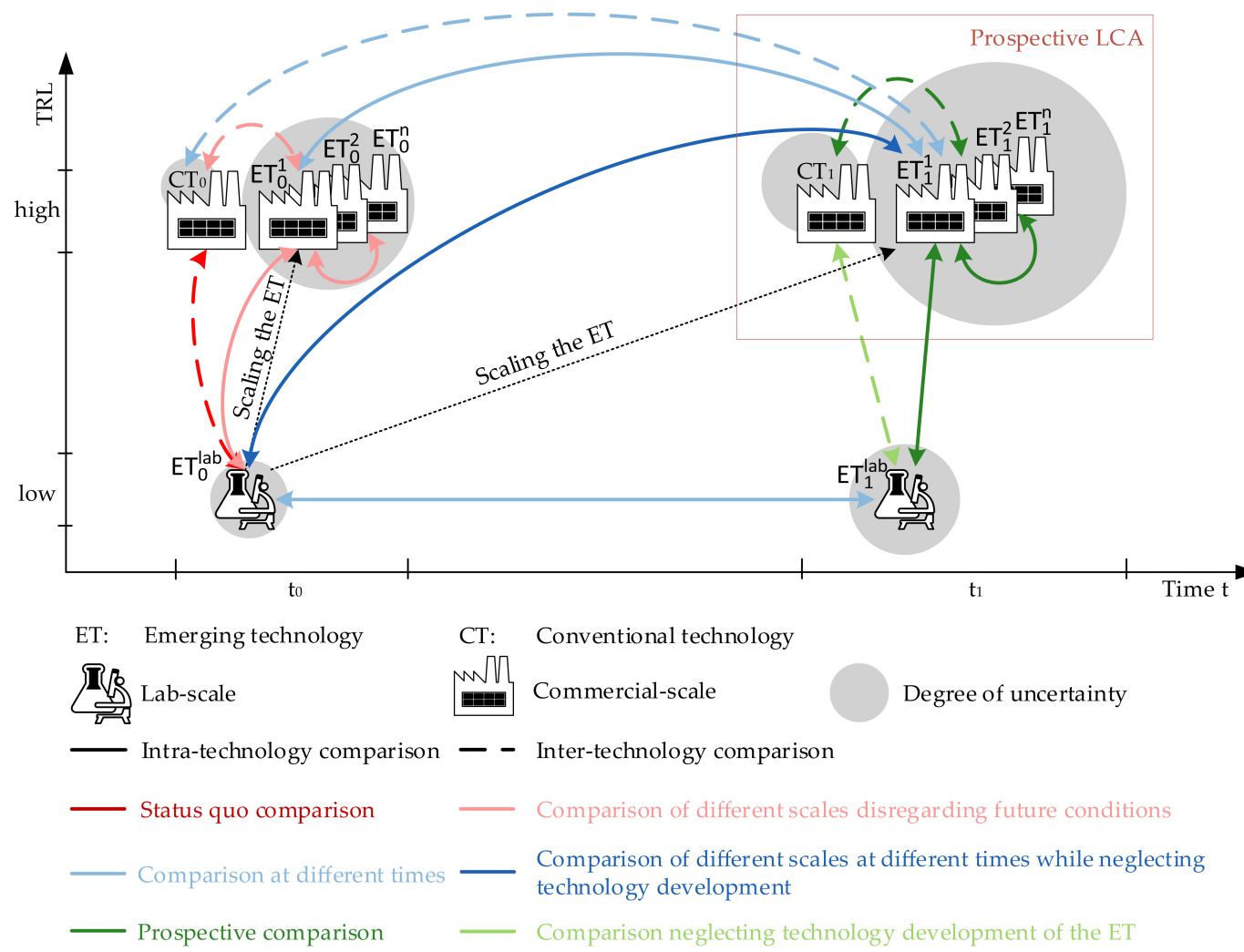

Figure 7. Schematic illustration of the comparison possibilities within the application of prospective LCAs including a temporal and technological development.

In Figure 7, the x-axis represents the temporal development with two different points in time, namely $t_{0}$ (current point in time) and $t_{1}$ (future point in time to which the technology is forecasted). The y-axis indicates the technological development of a technology, which is given by the TRL and differentiated between a "low" and a "high" TRL. 
The dotted black arrow in Figure 7 represents the scaling of the emerging technology from lab-scale at $\mathrm{t}_{0}\left(\mathrm{ET}_{0}^{\mathrm{lab}}\right)$ to commercial-scale without including the temporal development $\left(\mathrm{ET}_{0}^{1}\right.$ to $\left.\mathrm{ET}_{0}^{\mathrm{n}}\right)$ and with consideration to a future point in time $\mathrm{t}_{1}\left(\mathrm{ET}_{1}^{1}\right.$ to $\left.\mathrm{ET}_{1}^{\mathrm{n}}\right)$. Furthermore, the emerging technology at lab-scale $\left(\mathrm{ET}_{0}^{\mathrm{lab}}\right)$ can be projected and modeled according to different scenarios and assumptions (represented by $\mathrm{ET}_{0}^{1}, \mathrm{ET}_{0}^{2}$, and $\mathrm{ET}_{0}^{\mathrm{n}}$ at $\mathrm{t}_{0}$ and $\mathrm{ET}_{1}^{1}, \mathrm{ET}_{1}^{2}$, and $\mathrm{ET}_{1}^{\mathrm{n}}$ at $\mathrm{t}_{1}$ ).

Additionally, a distinction is made between an intra-technology comparison (comparison between ETs) and an inter-technology comparison (comparison of an emerging technology with a conventional technology). An intra-technology comparison, represented by solid-colored arrows in Figure 7, is made when different scenarios of the emerging technology are compared with each other. For example, different scale-up scenarios of the emerging technology are distinguished according to scale-up schemes at a future point in time $\left(\mathrm{ET}_{1}^{1}, \mathrm{ET}_{1}^{2}\right)$. An inter-technology comparison, represented by dashed colored arrows in Figure 7, is made when the emerging technology is compared to a conventional technology. An example of an inter-technology comparison is between an emerging technology with a high TRL and a conventional technology at a future point in time $\left(\mathrm{ET}_{1}^{1}\right.$ and $\left.\mathrm{CT}_{1}\right)$.

Prospective LCA, as defined by Arvidson et al. [17] includes both an assessment at a more-developed stage with a high TRL and at a projected future point in time $\left(t_{1}\right)$ (compare with Figure 7). Thus, a comparative LCA is prospective if the emerging technology is scaled to a high TRL and all technologies to be compared are modeled at the same future point in time $\left(t_{1}\right)$. The comparison between an emerging lab-scale technology with low TRL $\left(\mathrm{ET}_{0}^{\mathrm{lab}}\right)$ with an existing conventional technology with high TRL at the current time $\left(\mathrm{CT}_{0}\right)$ is not prospective as it compares the status quo without including technology development of the emerging technology (status quo comparison). Moreover, it is not sufficient to scale the emerging technology and to compare the scaled technology with either the lab-scale or another conventional technology in the current time $\left(\mathrm{t}_{0}\right)$. Such a comparison disregards the temporal development of a technology (e.g., comparisons of $\mathrm{ET}_{0}^{1}$ with $\mathrm{ET}_{0}^{\mathrm{lab}}$ or with $\mathrm{CT}_{0}$ ). However, it is inherent to these comparisons that the applied background data must be comparative. Otherwise, there is the chance of a comparability pitfall and can be traced back to a time-related issue due to different time-related background systems. To avoid comparability issues in the background system, the compared technologies, regardless of an inter- or intra-technology comparison, must be modeled at the same point in time. In conclusion, the comparison of a scaled emerging technology with either the same technology or with a conventional technology at the current time $\left(t_{0}\right)$ is not prospective. Such a comparison does not observe that the emerging technology will develop in the future regarding a technology and temporal development. Hence, the scaling of the emerging technology (technological development) and the modeling of future conditions (temporal development) are necessary for prospective LCAs (see also the section on data scaling).

Additionally, Figure 7 shows the different degrees of data uncertainty for LCAs at different technological and temporal development stages. The degree of uncertainty is higher when conducting an LCA for $\mathrm{ET}_{1}^{\mathrm{lab}}$ than for $\mathrm{ET}_{0}^{\mathrm{lab}}$ due to prospective background data (uncertainty due to temporal development). When scaling the $\mathrm{ET}_{0}^{\mathrm{lab}}$ to $\mathrm{ET}_{0}^{1}$, the uncertainty of LCAs increases due to the technological development. Uncertainty increases due to the temporal and technological development when conducting, for instance, a prospective LCA for $\mathrm{ET}_{1}^{1}$ (see uncertainty section for further detail).

\subsection{Framework for the Application of Prospective LCAs}

To tackle the challenges and issues posed by prospective LCAs, the proposed framework in Figure 8 provides methodological guidance. As a result of the systematic literature review, these methods are essential for the authors who conducted the methodological papers and case studies. The proposed approaches for addressing the challenges and issues obtained from the reviewed studies are aligned to the commonly known four-phase approach that is specified for conventional LCA in the ISO $14040 / 44[7,8]$. The proposed specifications for the application of prospective LCAs are to be applied in addition to the general steps in a conventional LCA as defined by ISO 14040/44 [7,8]. 


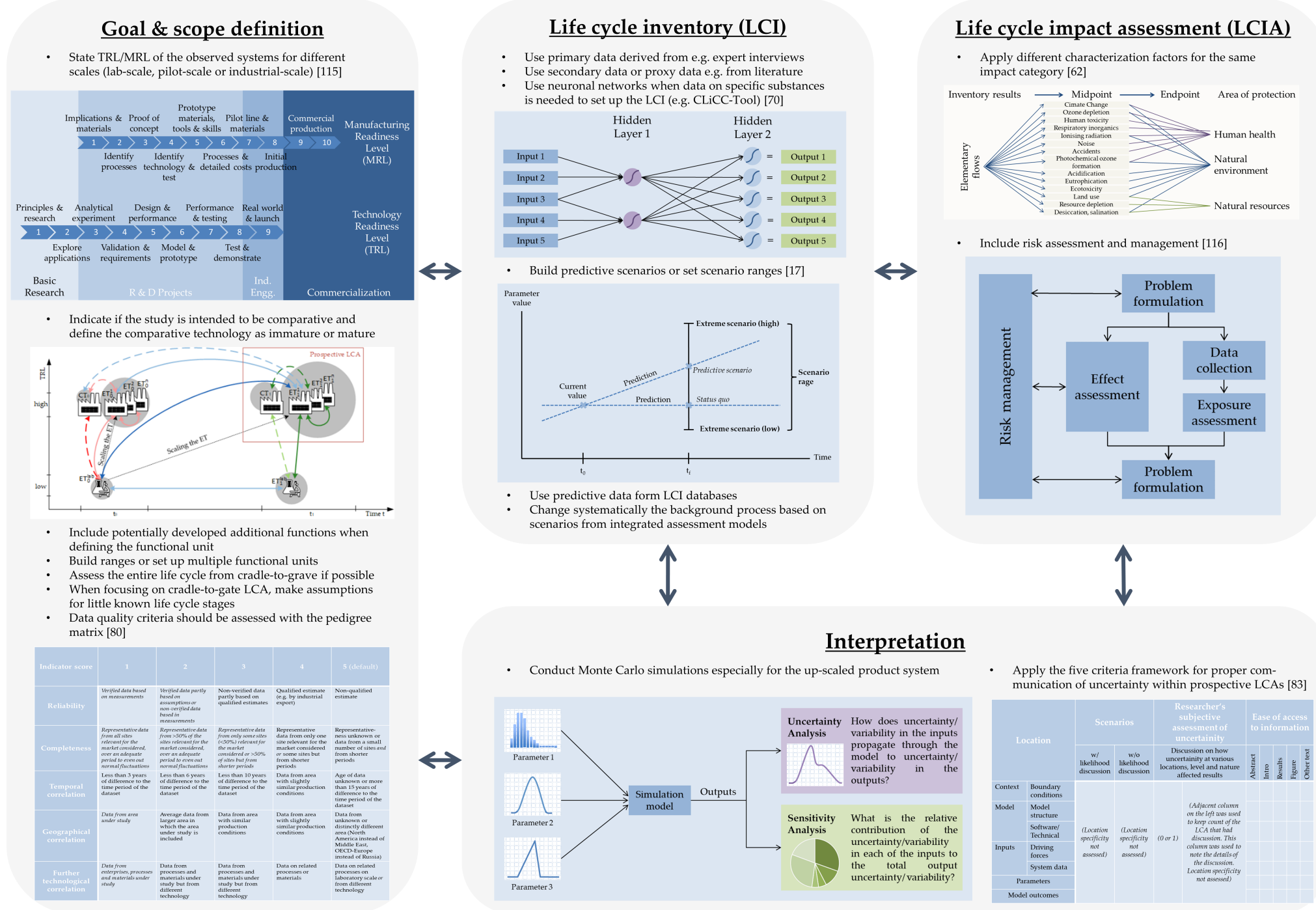

Figure 8. Methodological framework to overcome the challenges when applying prospective LCA (figures adapted from $[17,62,70,80,83,115,116])$. 
When defining the goal and scope, the TRL and MRL of the technology under study should be stated to comparatively indicate the development stage of the technology or technologies. Additionally, it should be described if a study is intentionally comparative and if it introduces the reference technology as immature or mature according to its TRL. When defining the functional unit, multiple functional units, such as those containing possible additional functions, should be included in a prospective LCA for emerging technologies. Multiple functional units can be tested in a sensitivity analysis in order to analyze the sensitivity that relies on the definition of the functional unit. If the system boundary is set from cradle-to-gate, assumptions for little-known life cycle stages should be made. In order to assess the data quality for the prospective LCA, the pedigree matrix should be applied according to Ciroth et al. [80]. For the LCI, primary data like expert interviews should be first used, and if no primary data is accessible, secondary or proxy data e.g., from the literature, should be used. If data is not accessible at all, neuronal networks can help to predict LCI data as shown in Song et al. [70]. Predictive scenarios or scenario ranges should be used for the scale-up. For the background system, data from databases should be used or data generated by integrated assessment models in order to assess the environmental impacts of emerging technologies at the correct point in time. Within the LCIA phase of a prospective LCA, different characterization factors for the same impact category, risk assessment, and management should be applied in order to include most environmental impact categories and to avoid burden shifting. For the interpretation phase, the data quality indices specified in the goal and scope definition can be used for uncertainty analysis. In order to communicate this uncertainty in prospective LCAs properly, the five criteria framework of Gavankar et al. [83] should be applied.

\section{Conclusions and Outlook}

The main goal of this study was to systematically review the literature on prospective LCAs of emerging technologies in order to identify the current state of research and to compile approaches for giving support in conducting a prospective LCA. Therefore, a review of 65 studies concerning prospective LCAs of emerging technologies was systematically conducted. From the identified articles, 44 of the reviewed publications are case studies. The case studies show that emerging technologies in the chemistry sector, such as $\mathrm{CO}_{2}$-based or bio-based chemicals, are mainly in focus. Nevertheless, environmental impacts of emerging technologies looking at nanomaterials, energy and biofuel generation, wastewater treatment, food production or mobility were conducted. Furthermore, 17 papers provide methodological guidance on how to perform prospective LCAs of emerging technologies, and four are review papers. The analysis of the literature shows that three main challenges exist when conducting prospective LCAs of emerging technologies: Comparability, data, and uncertainty. The second major finding was that several approaches exist to tackle these challenges. However, among the reviewed publication, none addressed the challenges comprehensively.

The findings of this study suggest that several approaches presented in the proposed framework should be applied when conducting prospective LCAs on emerging technologies. To be more transparent, for example, the TRL and MRL of the observed technology and, if necessary, comparative technology should be stated. In order to overcome data availability issues, we recommend conducting expert interviews, using literature data, or estimating data using neuronal networks. We also recommend conducting uncertainty and sensitivity analysis to improve the interpretation of results. In the case of emerging chemical processes such as the electrochemical reduction of $\mathrm{CO}_{2}$ to formic acid, it could be shown that applying uncertainty analysis to a prospective LCA enhances interpretation and decision-making for process engineers [78].

Nonetheless, a standardized approach for conducting prospective LCAs would ensure comparability and liability of such studies and is therefore needed. Most authors confirm the importance of standardization, since the scope of prospective LCAs is broader compared to conventional LCAs and leaves room for interpretation. Nonetheless, prospective LCAs lead to new insights and could guide policymakers. Prospective LCAs can also support designers or process engineers in the development 
of new products or technologies. Still, these findings are limited by the application of a qualitative review method. Additionally, the applied search strategy cannot prevent accidental exclusion of relevant studies. To avoid these accidental exclusions, several researchers performed the review process. Furthermore, our exclusion criteria limit the analysis.

Further research in this field is needed in the development of up-scaling schemes for emerging technologies. Thereby, the focus should be on uncertainty analyses. An evaluation of the reliability of scaling methods could be established by analyzing the up-scaling assumptions and models along with the development of a technology. By doing so, the quality of an up-scaling scheme could be assessed, evaluated, and validated.

Supplementary Materials: The following are available online at http:/www.mdpi.com/2071-1050/12/3/1192/s1, Table S1: Reviewed prospective LCA case studies on emerging technologies.

Author Contributions: Conceptualization, N.T.; methodology, N.T.; formal analysis, N.T. and A.S.; investigation, N.T. and A.S.; data curation, N.T. and A.S.; writing-original draft preparation, N.T. and A.S.; writing-review and editing, N.T., A.S. and D.M.; visualization, N.T. and A.S.; supervision, N.T. All authors have read and agreed to the published version of the manuscript.

Funding: This research received no external funding.

Conflicts of Interest: The authors declare no conflict of interest.

\section{References}

1. Zamagni, A. Life cycle sustainability assessment. Int. J. Life Cycle Assess. 2012, 17, 373-376. [CrossRef]

2. Daylan, B.; Ciliz, N. Life cycle assessment and environmental life cycle costing analysis of lignocellulosic bioethanol as an alternative transportation fuel. Renew. Energy 2016, 89, 578-587. [CrossRef]

3. Falcone, P.M.; González García, S.; Imbert, E.; Lijó, L.; Moreira, M.T.; Tani, A.; Tartiu, V.E.; Morone, P. Transitioning towards the bio-economy: Assessing the social dimension through a stakeholder lens. Corp. Soc. Responsib. Environ. Manag. 2019, 26. [CrossRef]

4. Falcone, P.; Imbert, E. Social Life Cycle Approach as a Tool for Promoting the Market Uptake of Bio-Based Products from a Consumer Perspective. Sustainability 2018, 10, 1031. [CrossRef]

5. Rafiaani, P.; Kuppens, T.; Van Dael, M.; Azadi, H.; Lebailly, P.; Van Passel, S. Social sustainability assessments in the biobased economy: Towards a systemic approach. Renew. Sustain. Energy Rev. 2018, 82, 1839-1853. [CrossRef]

6. Curran, M.A. Life Cycle Assessment: A review of the methodology and its application to sustainability. Curr. Opin. Chem. Eng. 2013, 2, 273-277. [CrossRef]

7. ISO. Environmental Management-Life Cycle Assessment-Principles and Framework; ISO: Geneva, Switzerland, 2009.

8. ISO. Environmental Management-Life Cycle Assessment-Requirements and Guidelines; ISO: Geneva, Switzerland, 2006.

9. Caduff, M.; Huijbregts, M.A.J.; Althaus, H.-J.; Hendriks, A.J. Power-law relationships for estimating mass, fuel consumption and costs of energy conversion equipments. Environ. Sci. Technol. 2011, 45, 751-754. [CrossRef] [PubMed]

10. Caduff, M.; Huijbregts, M.A.J.; Koehler, A.; Althaus, H.-J.; Hellweg, S. Scaling Relationships in Life Cycle Assessment. J. Ind. Ecol. 2014, 18, 393-406. [CrossRef]

11. Gasafi, E.; Weil, M.R. Approach and application of life cycle screening in early phases of process design: Case study of supercritical water gasification. J. Clean. Prod. 2011, 19, 1590-1600. [CrossRef]

12. Hetherington, A.C.; Borrion, A.L.; Griffiths, O.G.; McManus, M.C. Use of LCA as a development tool within early research: Challenges and issues across different sectors. Int. J. Life Cycle Assess. 2014, 19, 130-143. [CrossRef]

13. Hellweg, S.; Milà i Canals, L. Emerging approaches, challenges and opportunities in life cycle assessment. Science 2014, 344, 1109-1113. [CrossRef] [PubMed]

14. McKone, T.E.; Nazaroff, W.W.; Berck, P.; Auffhammer, M.; Lipman, T.; Torn, M.S.; Masanet, E.; Lobscheid, A.; Santero, N.; Mishra, U.; et al. Grand challenges for life-cycle assessment of biofuels. Environ. Sci. Technol. 2011, 45, 1751-1756. [CrossRef] [PubMed] 
15. Shibasaki, M.; Fischer, M.; Barthel, L. Effects on Life Cycle Assessment-Scale up of processes. In Advances in Life Cycle Engineering for Sustainable Manufacturing Businesses_-Proceedings of the 14th CIRP Conference on Life Cycle Engineering; Springer: London, UK, 2007.

16. Shibasaki, M.; Albrecht, S.; Kupfer, T. Small Scale and Large Scale Plants-Effect on Life Cycle Assessment. In 17th European Symposium on Computer Aided Process Engineering-ESCAPE17; Elsevier: Amsterdam, The Netherlands, 2007.

17. Arvidsson, R.; Tillman, A.-M.; Sandén, B.A.; Janssen, M.; Nordelöf, A.; Kushnir, D.; Molander, S. Environmental Assessment of Emerging Technologies: Recommendations for Prospective LCA: Recommendations for Prospective LCA. J. Ind. Ecol. 2018, 22, 1286-1294. [CrossRef]

18. Wender, B.A.; Foley, R.W.; Prado-Lopez, V.; Ravikumar, D.; Eisenberg, D.A.; Hottle, T.A.; Sadowski, J.; Flanagan, W.P.; Fisher, A.; Laurin, L.; et al. Illustrating anticipatory life cycle assessment for emerging photovoltaic technologies. Environ. Sci. Technol. 2014, 48, 10531-10538. [CrossRef] [PubMed]

19. Cucurachi, S.; Van der Giesen, C.; Guinée, J. Ex-ante LCA of Emerging Technologies. Procedia CIRP 2018, 69, 463-468. [CrossRef]

20. Buyle, M.; Audenaert, A.; Billen, P.; Boonen, K.; Van Passel, S. The Future of Ex-Ante LCA? Lessons Learned and Practical Recommendations. Sustainability 2019, 11, 5456. [CrossRef]

21. Moni, S.M.; Mahmud, R.; High, K.; Carbajales-Dale, M. Life cycle assessment of emerging technologies: A review. J. Ind. Ecol. 2019, 1. [CrossRef]

22. Arvidsson, R.; Kushnir, D.; Sandén, B.A.; Molander, S. Prospective Life Cycle Assessment of Graphene Production by Ultrasonication and Chemical Reduction. Environ. Sci. Technol. 2014, 48, 4529-4536. [CrossRef]

23. Arvidsson, R.; Molander, S. Prospective Life Cycle Assessment of Epitaxial Graphene Production at Different Manufacturing Scales and Maturity. J. Ind. Ecol. 2017, 21, 1153-1164. [CrossRef]

24. Krishna Manda, B.M.; Worrell, E.; Patel, M.K. Prospective life cycle assessment of an antibacterial T-shirt and supporting business decisions to create value. Resour. Conserv. Recycl. 2015, 103, 47-57. [CrossRef]

25. Spielmann, M.; Scholz, R.; Tietje, O.; Haan, P.D. Scenario Modelling in Prospective LCA of Transport Systems. Application of Formative Scenario Analysis (11 pp). Int. J. Life Cycle Assess. 2005, 10, 325-335. [CrossRef]

26. Walser, T.; Demou, E.; Lang, D.J.; Hellweg, S. Prospective environmental life cycle assessment of nanosilver T-shirts. Environ. Sci. Technol. 2011, 45, 4570-4578. [CrossRef] [PubMed]

27. Zimmermann, B.M.; Dura, H.; Baumann, M.J.; Weil, M.R. Prospective time-resolved LCA of fully electric supercap vehicles in Germany. Integr. Environ. Assess. Manag. 2015, 11, 425-434. [CrossRef] [PubMed]

28. Fink, A. Conducting Research Literature Reviews. From the Internet to Paper, 4th ed.; SAGE: Los Angeles, CA, USA, 2014; ISBN 1452259496.

29. Zumsteg, J.M.; Cooper, J.S.; Noon, M.S. Systematic Review Checklist: A Standardized Technique for Assessing and Reporting Reviews of Life Cycle Assessment Data. J. Ind. Ecol. 2012, 16, S12-S21. [CrossRef] [PubMed]

30. Rotolo, D.; Hicks, D.; Martin, B.R. What is an emerging technology? Res. Policy 2015, 44, 1827-1843. [CrossRef]

31. Mayring, P. Qualitative Inhaltsanalyse. Grundlagen und Techniken, 12th, ed.; Beltz: Weinheim, Germany, 2015; ISBN 3407257309.

32. Garcia-Herrero, I.; Cuéllar-Franca, R.M.; Enríquez-Gutiérrez, V.M.; Alvarez-Guerra, M.; Irabien, A.; Azapagic, A. Environmental Assessment of Dimethyl Carbonate Production: Comparison of a Novel Electrosynthesis Route Utilizing $\mathrm{CO}_{2}$ with a Commercial Oxidative Carbonylation Process. ACS Sustain. Chem. Eng. 2016, 4, 2088-2097. [CrossRef]

33. Roes, A.L.; Patel, M.K. Ex-ante environmental assessments of novel technologies-Improved caprolactam catalysis and hydrogen storage. J. Clean. Prod. 2011, 19, 1659-1667. [CrossRef]

34. Fang, L.L.; Valverde-Pérez, B.; Damgaard, A.; Plósz, B.G.; Rygaard, M. Life cycle assessment as development and decision support tool for wastewater resource recovery technology. Water Res. 2016, 88, 538-549. [CrossRef]

35. Sampaio, A.P.C.; De Men Sá, M.; Castro, A.L.A.; De Figueirêdo, M.C.B. Life cycle assessment from early development stages: The case of gelatin extracted from tilapia residues. Int. J. Life Cycle Assess. 2017, 22, 767-783. [CrossRef]

36. Tecchio, P.; Freni, P.; Benedetti, B.; De Fenouillot, F. Ex-ante Life Cycle Assessment approach developed for a case study on bio-based polybutylene succinate. J. Clean. Prod. 2016, 112, 316-325. [CrossRef] 
37. Zhou, Y.; Lee, C.K.; Sharratt, P. Bridging the Gap from Pilot Plant Experimental Records to Life Cycle Inventory. Ind. Eng. Chem. Res. 2017, 56, 10393-10412. [CrossRef]

38. Kazemi, A.; Bahramifar, N.; Heydari, A.; Olsen, S.I. Life cycle assessment of nanoadsorbents at early stage technological development. J. Clean. Prod. 2018, 174, 527-537. [CrossRef]

39. Villares, M.; Işıldar, A.; Mendoza Beltran, A.; Guinee, J. Applying an ex-ante life cycle perspective to metal recovery from e-waste using bioleaching. J. Clean. Prod. 2016, 129, 315-328. [CrossRef]

40. Hung, C.R.; Ellingsen, L.A.-W.; Majeau-Bettez, G. LiSET: A Framework for Early-Stage Life Cycle Screening of Emerging Technologies. J. Ind. Ecol. 2018, 41, 105. [CrossRef]

41. Corona, A.; Ambye-Jensen, M.; Vega, G.C.; Hauschild, M.Z.; Birkved, M. Techno-environmental assessment of the green biorefinery concept: Combining process simulation and life cycle assessment at an early design stage. Sci. Total Environ. 2018, 635, 100-111. [CrossRef] [PubMed]

42. Corona, A.; Parajuli, R.; Ambye-Jensen, M.; Hauschild, M.Z.; Birkved, M. Environmental screening of potential biomass for green biorefinery conversion. J. Clean. Prod. 2018, 189, 344-357. [CrossRef]

43. Gavankar, S.; Suh, S.; Keller, A.A. The Role of Scale and Technology Maturity in Life Cycle Assessment of Emerging Technologies: A Case Study on Carbon Nanotubes: A Case Study on Carbon Nanotubes. J. Ind. Ecol. 2015, 19, 51-60. [CrossRef]

44. Taelman, S.E.; Meester, S.; De Roef, L.; Michiels, M.; Dewulf, J. The environmental sustainability of microalgae as feed for aquaculture: A life cycle perspective. Bioresour. Technol. 2013, 150, 513-522. [CrossRef]

45. Troy, S.; Schreiber, A.; Reppert, T.; Gehrke, H.-G.; Finsterbusch, M.; Uhlenbruck, S.; Stenzel, P. Life Cycle Assessment and resource analysis of all-solid-state batteries. Appl. Energy 2016, 169, 757-767. [CrossRef]

46. Hischier, R.; Salieri, B.; Pini, M. Most important factors of variability and uncertainty in an LCA study of nanomaterials-Findings from a case study with nano titanium dioxide. NanoImpact 2017, 7, 17-26. [CrossRef]

47. Reap, J.; Roman, F.; Duncan, S.; Bras, B. A survey of unresolved problems in life cycle assessment. Int. J. Life Cycle Assess. 2008, 13, 290-300. [CrossRef]

48. Thomassen, G.; Van Dael, M.; Van Passel, S.; You, F. How to assess the potential of emerging green technologies? Towards a prospective environmental and techno-economic assessment framework. Green Chem. 2019, 21, 4868-4886. [CrossRef]

49. Gear, M.; Sadhukhan, J.; Thorpe, R.; Clift, R.; Seville, J.; Keast, M. A life cycle assessment data analysis toolkit for the design of novel processes-A case study for a thermal cracking process for mixed plastic waste. J. Clean. Prod. 2018, 180, 735-747. [CrossRef]

50. Miller, S.A.; Keoleian, G.A. Framework for analyzing transformative technologies in life cycle assessment. Environ. Sci. Technol. 2015, 49, 3067-3075. [CrossRef]

51. Simon, B.; Bachtin, K.; Kiliç, A.; Amor, B.; Weil, M. Proposal of a framework for scale-up life cycle inventory: A case of nanofibers for lithium iron phosphate cathode applications. Integr. Environ. Assess. Manag. 2016, 12, 465-477. [CrossRef]

52. Piccinno, F.; Hischier, R.; Seeger, S.; Som, C. From laboratory to industrial scale: A scale-up framework for chemical processes in life cycle assessment studies. J. Clean. Prod. 2016, 135, 1085-1097. [CrossRef]

53. Arvidsson, R.; Nguyen, D.; Svanström, M. Life cycle assessment of cellulose nanofibrils production by mechanical treatment and two different pretreatment processes. Environ. Sci. Technol. 2015, 49, 6881-6890. [CrossRef]

54. Fazeni, K.; Lindorfer, J.; Prammer, H. Methodological advancements in Life Cycle Process Design: A preliminary outlook. Resour. Conserv. Recycl. 2014, 92, 66-77. [CrossRef]

55. Lu, J.; Kumagai, S.; Ohno, H.; Kameda, T.; Saito, Y.; Yoshioka, T.; Fukushima, Y. Deducing targets of emerging technologies based on ex ante life cycle thinking: Case study on a chlorine recovery process for polyvinyl chloride wastes. Resour. Conserv. Recycl. 2019, 151. [CrossRef]

56. Suh, S.; Lenzen, M.; Treloar, G.J.; Hondo, H.; Horvath, A.; Huppes, G.; Jolliet, O.; Klann, U.; Krewitt, W.; Moriguchi, Y.; et al. System Boundary Selection in Life-Cycle Inventories Using Hybrid Approaches. Environ. Sci. Technol. 2004, 38, 657-664. [CrossRef]

57. Villares, M.; Işıldar, A.; Van der Giesen, C.; Guinée, J. Does ex ante application enhance the usefulness of LCA: A case study on an emerging technology for metal recovery from E-Waste. Int. J. Life Cycle Assess. 2017, 22, 1618-1633. [CrossRef] 
58. Hospido, A.; Davis, J.; Berlin, J.; Sonesson, U. A review of methodological issues affecting LCA of novel food products. Int. J. Life Cycle Assess. 2010, 15, 44-52. [CrossRef]

59. Caduff, M.; Huijbregts, M.A.J.; Althaus, H.-J.; Koehler, A.; Hellweg, S. Wind power electricity: The bigger the turbine, the greener the electricity? Environ. Sci. Technol. 2012, 46, 4725-4733. [CrossRef] [PubMed]

60. Janssen, M.; Tillman, A.-M.; Cannella, D.; Jørgensen, H. Influence of high gravity process conditions on the environmental impact of ethanol production from wheat straw. Bioresour. Technol. 2014, 173, 148-158. [CrossRef]

61. Yao, Y.; Masanet, E. Life-cycle modeling framework for generating energy and greenhouse gas emissions inventory of emerging technologies in the chemical industry. J. Clean. Prod. 2018, 172, 768-777. [CrossRef]

62. EC-JRC. International Reference Life Cycle Data System (ILCD) Handbook. General Guide for Life Cycle Assessment: Detailed Guidance; EUR: Luxembourg, 2010.

63. Pourzahedi, L.; Pandorf, M.; Ravikumar, D.; Zimmerman, J.B.; Seager, T.P.; Theis, T.L.; Westerhoff, P.; Gilbertson, L.M.; Lowry, G.V. Life cycle considerations of nano-enabled agrochemicals: Are today's tools up to the task? Environ. Sci. Nano 2018, 5, 1057-1069. [CrossRef]

64. Valsasina, L.; Pizzol, M.; Smetana, S.; Georget, E.; Mathys, A.; Heinz, V. Life cycle assessment of emerging technologies: The case of milk ultra-high pressure homogenisation. J. Clean. Prod. 2017, 142, 2209-2217. [CrossRef]

65. Zackrisson, M.; Jönsson, C.; Johannisson, W.; Fransson, K.; Posner, S.; Zenkert, D.; Lindbergh, G. Prospective Life Cycle Assessment of a Structural Battery. Sustainability 2019, 11, 5679. [CrossRef]

66. Gasafi, E.; Meyer, L.; Liselotte, S. Using Life-Cycle Assessment in Process Design: Supercritical Water Gasification of Organic Feedstocks. J. Ind. Ecol. 2004, 7, 75-91. [CrossRef]

67. Sousa, I.; Wallace, D.; Eisenhard, J.L. Approximate Life-Cycle Assessment of Product Concepts Using Learning Systems. J. Ind. Ecol. 2008, 4, 61-81. [CrossRef]

68. Wernet, G.; Bauer, C.; Steubing, B.; Reinhard, J.; Moreno-Ruiz, E.; Weidema, B. The ecoinvent database version 3 (part I): Overview and methodology. Int. J. Life Cycle Assess. 2016, 21, 1218-1230. [CrossRef]

69. Thinkstep. GaBi Software-System and Database for Life Cycle Engineering. 2016. Available online: http://www.gabi-software.com/deutsch/index/ (accessed on 29 April 2016).

70. Song, R.; Keller, A.A.; Suh, S. Rapid Life-Cycle Impact Screening Using Artificial Neural Networks. Environ. Sci. Technol. 2017, 51, 10777-10785. [CrossRef] [PubMed]

71. Pallas, G.; Vijver, M.G.; Peijnenburg, W.J.G.M.; Guinée, J. Life cycle assessment of emerging technologies at the lab scale: The case of nanowire-based solar cells. J. Ind. Ecol. 2019, 8, 733. [CrossRef]

72. Smetana, S.; Palanisamy, M.; Mathys, A.; Heinz, V. Sustainability of insect use for feed and food: Life Cycle Assessment perspective. J. Clean. Prod. 2016, 137, 741-751. [CrossRef]

73. Tsoy, N.; Prado, V.; Wypkema, A.; Quist, J.; Mourad, M. Anticipatory Life Cycle Assessment of sol-gel derived anti-reflective coating for greenhouse glass. J. Clean. Prod. 2019, 221, 365-376. [CrossRef]

74. Yao, Y.; Hu, M.; Di Maio, F.; Cucurachi, S. Life cycle assessment of 3D printing geo-polymer concrete: An ex-ante study. J. Ind. Ecol. 2019. [CrossRef]

75. Wender, B.A.; Foley, R.W.; Hottle, T.A.; Sadowski, J.; Prado-Lopez, V.; Eisenberg, D.A.; Laurin, L.; Seager, T.P. Anticipatory life-cycle assessment for responsible research and innovation. J. Responsible Innov. 2014, 1, 200-207. [CrossRef]

76. Baresel, C.; Dahlgren, L.; Almemark, M.; Lazic, A. Municipal wastewater reclamation for non-potable reuse-Environmental assessments based on pilot-plant studies and system modelling. Water Sci. Technol. 2015, 72, 1635-1643. [CrossRef]

77. Joyce, P.J.; Hertel, T.; Goronovski, A.; Tkaczyk, A.H.; Pontikes, Y.; Björklund, A. Identifying hotspots of environmental impact in the development of novel inorganic polymer paving blocks from bauxite residue. Resour. Conserv. Recycl. 2018, 138, 87-98. [CrossRef]

78. Thonemann, N.; Schulte, A. From Laboratory to Industrial Scale: A Prospective LCA for Electrochemical Reduction of $\mathrm{CO}_{2}$ to Formic Acid. Environ. Sci. Technol. 2019, 53, 12320-12329. [CrossRef]

79. Weidema, B.P.; Wesnæs, M.S. Data quality management for life cycle inventories-An example of using data quality indicators. J. Clean. Prod. 1996, 4, 167-174. [CrossRef]

80. Ciroth, A.; Muller, S.; Weidema, B.; Lesage, P. Empirically based uncertainty factors for the pedigree matrix in ecoinvent. Int. J. Life Cycle Assess. 2016, 21, 1338-1348. [CrossRef] 
81. Muller, S.; Lesage, P.; Ciroth, A.; Mutel, C.; Weidema, B.P.; Samson, R. The application of the pedigree approach to the distributions foreseen in ecoinvent v3. Int. J. Life Cycle Assess. 2016, 21, 1327-1337. [CrossRef]

82. Mendoza Beltran, A.; Cox, B.; Mutel, C.; Van Vuuren, D.P.; Font Vivanco, D.; Deetman, S.; Edelenbosch, O.Y.; Guinée, J.; Tukker, A. When the Background Matters: Using Scenarios from Integrated Assessment Models in Prospective Life Cycle Assessment. J. Ind. Ecol. 2018, 99, 111. [CrossRef]

83. Gavankar, S.; Anderson, S.; Keller, A.A. Critical Components of Uncertainty Communication in Life Cycle Assessments of Emerging Technologies. J. Ind. Ecol. 2015, 19, 468-479. [CrossRef]

84. Shibasaki, M.; Warburg, N.; Eyerer, P. Upscaling effect and Life Cycle Assessment. In Proceedings of the 13th CIRP International Conference on Life Cycle Engineering, Leuven, Belgium, 31 May-2 June 2006; pp. 61-64.

85. Bergesen, J.D.; Suh, S. A framework for technological learning in the supply chain: A case study on CdTe photovoltaics. Appl. Energy 2016, 169, 721-728. [CrossRef]

86. Rubin, E.S.; Azevedo, I.M.L.; Jaramillo, P.; Yeh, S. A review of learning rates for electricity supply technologies. Energy Policy 2015, 86, 198-218. [CrossRef]

87. Bartolozzi, I.; Daddi, T.; Punta, C.; Fiorati, A.; Iraldo, F. Life cycle assessment of emerging environmental technologies in the early stage of development: A case study on nanostructured materials. J. Ind. Ecol. 2019, 2, 1010. [CrossRef]

88. Haupt, G. Learning from experts: Fostering extended thinking in the early phases of the design process. Int. J. Technol. Des. Educ. 2015, 25, 483-520. [CrossRef]

89. Gerber, L.; Gassner, M.; Maréchal, F. Systematic integration of LCA in process systems design: Application to combined fuel and electricity production from lignocellulosic biomass. Comput. Chem. Eng. 2011, 35, 1265-1280. [CrossRef]

90. Pini, M.; Cedillo González, E.; Neri, P.; Siligardi, C.; Ferrari, A. Assessment of Environmental Performance of TiO2 Nanoparticles Coated Self-Cleaning Float Glass. Coatings 2017, 7, 8. [CrossRef]

91. Weyand, S.; Wittich, C.; Schebek, L. Environmental performance of emerging photovoltaic technologies: Assessment of the status quo and future prospects based on a meta-analysis of life-cycle assessment studies. Energies 2019, 12, 4228. [CrossRef]

92. Pesonen, H.-L.; Ekvall, T.; Fleischer, G.; Huppes, G.; Jahn, C.; Klos, Z.S.; Rebitzer, G.; Sonnemann, G.W.; Tintinelli, A.; Weidema, B.P.; et al. Framework for scenario development in LCA. Int. J. Life Cycle Assess. 2000, 5, 21-30. [CrossRef]

93. Sharp, B.E.; Miller, S.A. Potential for Integrating Diffusion of Innovation Principles into Life Cycle Assessment of Emerging Technologies. Environ. Sci. Technol. 2016, 50, 2771-2781. [CrossRef]

94. Cox, B.; Mutel, C.L.; Bauer, C.; Mendoza Beltran, A.; Van Vuuren, D.P. Uncertain Environmental Footprint of Current and Future Battery Electric Vehicles. Environ. Sci. Technol. 2018, 52, 4989-4995. [CrossRef] [PubMed]

95. Gibon, T.; Wood, R.; Arvesen, A.; Bergesen, J.D.; Suh, S.; Hertwich, E.G. A Methodology for Integrated, Multiregional Life Cycle Assessment Scenarios under Large-Scale Technological Change. Environ. Sci. Technol. 2015, 49, 11218-11226. [CrossRef] [PubMed]

96. Van der Voet, E.; Van Oers, L.; Verboon, M.; Kuipers, K. Environmental Implications of Future Demand Scenarios for Metals: Methodology and Application to the Case of Seven Major Metals. J. Ind. Ecol. 2019, 23, 141-155. [CrossRef]

97. Jones, C.; Gilbert, P.; Raugei, M.; Mander, S.; Leccisi, E. An approach to prospective consequential life cycle assessment and net energy analysis of distributed electricity generation. Energy Policy 2017, 100, 350-358. [CrossRef]

98. Sandén, B.A.; Karlström, M. Positive and negative feedback in consequential life-cycle assessment. J. Clean. Prod. 2007, 15, 1469-1481. [CrossRef]

99. Liptow, C.; Tillman, A.-M.; Janssen, M. Life cycle assessment of biomass-based ethylene production in Sweden-Is gasification or fermentation the environmentally preferable route? Int. J. Life Cycle Assess. 2015, 20, 632-644. [CrossRef]

100. Sandén, B.A.; Jonasson, K.M.; Karlström, M.; Tillman, A.-M. LCA of Emerging Technologies: A Methodological Framework. In Proceedings of the LCM 2005-Innovation by Life Cycle Management, International Conference, Barcelona, Spain, 5-7 September 2005. 
101. Muñoz, I.; Portillo, F.; Rosiek, S.; Batlles, F.J.; Martínez-Del-Río, J.; Acasuso, I.; Piergrossi, V.; De Sanctis, M.; Chimienti, S.; Di Iaconi, C. Prospective environmental and economic assessment of solar-assisted thermal energy recovery from wastewater through a sequencing batch biofilter granular reactor. J. Clean. Prod. 2019, 212, 1300-1309. [CrossRef]

102. Bergerson, J.A.; Brandt, A.; Cresko, J.; Carbajales-Dale, M.; MacLean, H.L.; Matthews, H.S.; McCoy, S.; McManus, M.; Miller, S.A.; Morrow, W.R.; et al. Life cycle assessment of emerging technologies: Evaluation techniques at different stages of market and technical maturity. J. Ind. Ecol. 2019, 33, 101. [CrossRef]

103. Huijbregts, M.A.J.; Gilijamse, W.; Ragas, A.D.M.J.; Reijnders, L. Evaluating Uncertainty in Environmental Life-Cycle Assessment. A Case Study Comparing Two Insulation Options for a Dutch One-Family Dwelling. Environ. Sci. Technol. 2003, 37, 2600-2608. [CrossRef] [PubMed]

104. Cooper, D.R.; Gutowski, T.G. Prospective Environmental Analyses of Emerging Technology: A Critique, a Proposed Methodology, and a Case Study on Incremental Sheet Forming. J. Ind. Ecol. 2018, $219,239$. [CrossRef]

105. Lacirignola, M.; Blanc, P.; Girard, R.; Pérez-López, P.; Blanc, I. LCA of emerging technologies: Addressing high uncertainty on inputs' variability when performing global sensitivity analysis. Sci. Total Environ. 2017, 578, 268-280. [CrossRef] [PubMed]

106. Marini, C.; Blanc, I. Towards Prospective Life Cycle Assessment: How to Identify Key Parameters Inducing Most Uncertainties in the Future? Application to Photovoltaic Systems Installed in Spain. In Computational Science and Its Applications-ICCSA 2014; Murgante, B., Misra, S., Roch, A.M.A.C., Torre, C., Rocha, J.G., Falcão, M.I., Taniar, D., Apduhan, B.O., Gervasi, O., Eds.; Springer: New York, NY, USA, 2014; pp. 691-706.

107. Ravikumar, D.; Seager, T.P.; Cucurachi, S.; Prado, V.; Mutel, C. Novel Method of Sensitivity Analysis Improves the Prioritization of Research in Anticipatory Life Cycle Assessment of Emerging Technologies. Environ. Sci. Technol. 2018, 52, 6534-6543. [CrossRef] [PubMed]

108. Piccinno, F.; Hischier, R.; Seeger, S.; Som, C. Predicting the environmental impact of a future nanocellulose production at industrial scale: Application of the life cycle assessment scale-up framework. J. Clean. Prod. 2018, 174, 283-295. [CrossRef]

109. De Marco, I.; Iannone, R.; Miranda, S.; Riemma, S. An environmental study on starch aerogel for drug delivery applications: Effect of plant scale-up. Int. J. Life Cycle Assess. 2017, 303, 1818. [CrossRef]

110. Sfez, S.; Van den Hende, S.; Taelman, S.E.; De Meester, S.; Dewulf, J. Environmental sustainability assessment of a microalgae raceway pond treating aquaculture wastewater: From up-scaling to system integration. Bioresour. Technol. 2015, 190, 321-331. [CrossRef]

111. Tan, L.; Mandley, S.J.; Peijnenburg, W.J.G.M.; Van der Waaijers Loop, S.L.; Giesen, D.; Legradi, J.B.; Shen, L. Combining ex-ante LCA and EHS screening to assist green design: A case study of cellulose nanocrystal foam. J. Clean. Prod. 2018, 178, 494-506. [CrossRef]

112. Clavreul, J.; Christensen, T.H.; Baumeister, H. LCA of Waste Management Systems: Development of Tools for Modeling and Uncertainty Analysis; DTU Environment: Kongens Lyngby, Denmark, 2013.

113. Gargalo, C.L.; Cheali, P.; Posada, J.A.; Carvalho, A.; Gernaey, K.V.; Sin, G. Assessing the environmental sustainability of early stage design for bioprocesses under uncertainties: An analysis of glycerol bioconversion. J. Clean. Prod. 2016, 139, 1245-1260. [CrossRef]

114. Frischknecht, R.; Jungbluth, N.; Althaus, H.-J.; Doka, G.; Dones, R.; Heck, T.; Hellweg, S.; Hischier, R.; Nemecek, T.; Rebitzer, G.; et al. The ecoinvent Database: Overview and Methodological Framework (7 pp). Int. J. Life Cycle Assess. 2005, 10, 3-9. [CrossRef]

115. Fernandez, J.A. Contextual Role of TRLs and MRLs in Technology Management; Sandia National Lab-CRF: Livermore, CA, USA, 2010.

116. Barberio, G.; Scalbi, S.; Buttol, P.; Masoni, P.; Righi, S. Combining life cycle assessment and qualitative risk assessment: The case study of alumina nanofluid production. Sci. Total Environ. 2014, 496, 122-131. [CrossRef] [PubMed]

(C) 2020 by the authors. Licensee MDPI, Basel, Switzerland. This article is an open access article distributed under the terms and conditions of the Creative Commons Attribution (CC BY) license (http://creativecommons.org/licenses/by/4.0/). 